\title{
Life Cycle Assessment of Recirculating Aquaculture Systems: A case of Atlantic salmon farming in China
}

Xingqiang Song ${ }^{1,2}$, Ying Liu ${ }^{3}$, Johan Berg Pettersen ${ }^{1,4}$, Miguel Brandão ${ }^{5}$, Xiaona $\mathrm{Ma}^{6}$, Stian Røberg ${ }^{1}$, and Björn Frostell ${ }^{5}$

${ }^{1}$ Faculty of Biosciences, Fisheries and Economics, The Arctic University of Norway, Troms $\varnothing$, Norway

${ }^{2}$ Ecoloop AB, Stockholm, Sweden

${ }^{3}$ School of Marine Science and Environment Engineering, Dalian Ocean University, Dalian, China

${ }^{4}$ Industrial Ecology Programme, Norwegian University of Science and Technology, Trondheim, Norway

${ }^{5}$ Department of Sustainable Development, Environmental Science and Engineering, KTH Royal Institute of Technology, Stockholm, Sweden

${ }^{6}$ Institute of Oceanology, Chinese Academy of Sciences, Qingdao, China

\section{Correspondence:}

Ying Liu, School of Marine Science and Environment Engineering, Dalian Ocean University, 116023 Dalian, China. Email: yingliu@dlou.edu.cn

\begin{abstract}
Recirculating aquaculture systems (RAS) is an alternative technology to tackle the major environmental challenges associated with conventional cage culture systems. In order to systematically assess the environmental performance of RAS farming, it is important to take the whole life cycle into account so as to avoid ad-hoc and suboptimal environmental measures. So far, the application of life cycle assessment (LCA) in aquaculture, especially to indoor RAS, is still in progress. This study reported on an LCA of Atlantic salmon harvested at an indoor RAS farm in northern China. Results showed that 1 tonne live-weight salmon production required $7509 \mathrm{kWh}$ farm-level electricity, and generated 16.7 tonnes of $\mathrm{CO}_{2}$ equivalent (eq), $106 \mathrm{~kg}$ of SO $2 \mathrm{eq}, 2.4 \mathrm{~kg}$ of $\mathrm{P}$ eq, and $108 \mathrm{~kg}$ of $\mathrm{N}$ eq (cradle-to-farm gate). In particular, farm-level electricity use and feed product were identified as primary contributors to eight of nine impact categories assessed (ranging $54-95 \%$ in total), except the potential marine eutrophication impact (dominated by the grow-out effluents). Among feed ingredients (on a dry-weight basis), chicken meal (5\%) and krill meal (8\%) dominated six and three, respectively, of the nine impact categories. Suggested environmental improvement measures for this indoor RAS farm included optimization of stocking density, feeding management, grow-out effluent treatment, substitution of feed ingredients, and selection of electricity generation sources. In a generic context, this study can contribute to a better understanding of the life cycle environmental impacts of land-based salmon RAS operations, as well as science-based communication among stakeholders on more eco-friendly farmed salmon.
\end{abstract}

\section{KEYWORDS}

Atlantic salmon, feed production, indoor aquaculture, industrial ecology, life cycle assessment (LCA), recirculating aquaculture systems

\section{Funding Information}

Research Council of Norway through NORDSATSNING (grant number 195160), and Eni Norge AS. 


\section{INTRODUCTION}

Development of a sustainable aquaculture industry plays a key role in meeting global food and nutrition security (HLPE 2014). Aquaculture is the world's fastest growing food production sector, which is projected to supply over $60 \%$ of fish for direct human consumption by 2030 (World Bank 2013). Among the main groups of species in world trade, salmon and trout became the largest single commodity by value in 2013, and demand is growing steadily, especially for farmed Atlantic salmon (FAO 2016). At present, farmed Atlantic salmon (Salmo salar) accounts for around $60 \%$ of the world's salmon production (Pawlowski et al. 2016). The current commercial-scale salmon grow-out takes place mostly in cage aquaculture, though salmon smolts have been produced on land (Bergheim et al. 2009). Despite measures taken to alleviate environmental impacts of the traditional open net-cage salmon farming, significant problems and constraints in relation to parasites (sea lice), diseases and the escape of fish have proved difficult to overcome (Lekang et al. 2016).

Recent efforts to tackle the challenges faced by open-net-cage aquaculture have been shifted to the development of mitigation measures and alternative farming methods, such as closed-containment systems. In particular, the intensive land-based recirculating aquaculture systems (RAS) technology is regarded as having considerable growth potential (Dalsgaard et al. 2013). According to Ebeling and Timmons (2012), indoor aquaculture is probably the only potential method to ensure a relatively high level of seafood safety. In the case of post-smolt Atlantic salmon farming to marketable size, there are currently only a few land-based RAS in operation, mainly located in Denmark, China, and Canada (Iversen et al. 2013).

The environmental impacts of the entire seafood value chain have been a high-priority issue for the pursuit of sustainable aquaculture development. In order to assess the environmental impacts of RAS farming in a systems perspective, it is important to take into account the whole fish supply chain, beyond the traditional focus of environmental engineering and risk assessment at farm site. Understanding the life cycle impacts associated with expanding and intensifying aquaculture is also crucial for designing responsible aquaculture systems (Diana et al. 2013). This has therefore resulted in a growing interest in employing life cycle thinking-based methodology to assess the overall environmental impacts of seafood production systems.

Life cycle assessment (LCA) is an internationally standardized method for addressing the environmental aspects and potential environmental impacts throughout a product's life cycle (ISO 2006). Although LCA has been widely used in the food industry (Sonesson et al. 2010), the application of LCA in aquaculture began in the mid-2000s. The first published aquaculture LCA study (Papatryphon et al. 2004) focuses on environmental impact assessment of the entire life cycle of salmonid feeds with different ingredient compositions. In recent years, LCA has proven to be a valuable tool for assessing the potential environmental impacts of aquaculture production systems and informing certification and eco-labelling criteria for the seafood sector (Cao et al. 2013). The application of LCA to seafood supply chains has demonstrated some previously unassessed environmental impacts of fisheries and aquaculture, leading to new insights into the environmental impacts of seafood products, such as those related to greenhouse gases, toxic emissions, eutrophication, and land use (Ziegler et al. 2016).

The application of LCA in salmonid RAS is still in progress. In the past decade, only a number of LCA studies on salmonid aquaculture systems were published, with varying goals and scopes (see Table S1 in the Supporting Information available on the Web). For instance, Ayer and Tyedmers (2009) conducted an LCA of four salmonid culture systems in Canada (i.e., Atlantic salmon farmed in marine open net, marine floating bag and land-based flow-through systems, as well as Arctic char in land-based recirculating system), and they emphasized the need for further assessment of the environmental impacts of material and energy requirements of closed-containment aquaculture. McGrath et al. (2015) carried out an LCA of a floating tank, flow-through and solid-walled system for Chinook salmon farming in Canada, and presented the primary contributions from feed provisioning and on-site energy use. Liu et al. (2016) compared an 
open net pen system in Norway with a hypothetical land-based RAS in the US for producing Atlantic salmon, focusing on economic performance and carbon footprint. Due to few published LCA studies on recirculating salmonid fish farming, it becomes difficult to systematically assess the environmental impacts of salmon farmed in RAS, as well as to benchmark the materials and energy requirements of RAS with other salmon farming methods.

So far, there has been no published LCA of indoor salmon RAS farming, based on actual operations at commercial scale. While some salmonid aquaculture LCA publications include the farm-level energy use, few of them give a breakdown of the total electricity use at the most important sub-process level. As emphasized in a recent review of LCA on aquaculture systems by Bohnes and Laurent (2018), one future need of aquaculture LCAs is to construct aquaculture life cycle inventory databases with a special need for developing countries.

This paper presented the results of life cycle inventory and life cycle impacts of Atlantic salmon (Salmo salar) harvested in a commercial scale indoor RAS farm in northern China. In a generic context, results of this study can contribute to an improved understanding of the life cycle environmental impacts of salmon produced in land-based RAS and science-based communication among stakeholders on more eco-friendly farmed salmon.

\section{METHODOLOGY AND DATA SOURCES}

\subsection{Life cycle assessment}

\subsubsection{Goal and scope definition}

The goal of the present LCA study was twofold: first, to assess the potential environmental impacts associated with the Atlantic salmon RAS farming system under study (for details of the RAS farm and feed formulations, see Table S2 in the Supporting Information available on the Web), and then to identify environmental hotspots of the whole fish production chain. The functional unit of this study was one tonne harvest-ready live-weight Atlantic salmon at the grow-out farm. The system boundaries were from cradle to farm gate, beginning with resource extraction and ending with harvest-ready salmon at the grow-out farm gate (Figure 1).

Both foreground (feed manufacturing, hatchery \& smolt rearing, and salmon grow-out) and background (e.g. energy generation, manufacturing, and feed ingredients production) processes were included. Due to data limitation, three inventory parameters of the smolt hatchery \& rearing and feed manufacturing plants were not considered in this study, including infrastructure, on-site wastes and emissions, and transport of raw feed ingredients to the feed manufacturing plant. Among farm-level emissions, only nutrient emissions from the grow-out farm to the receiving water were considered.

This study assessed nine impact categories, including climate change ( $\left.\mathrm{kg} \mathrm{CO}_{2} \mathrm{eq}\right)$, terrestrial acidification ( $\mathrm{kg} \mathrm{SO}_{2} \mathrm{eq}$ ), freshwater eutrophication ( $\mathrm{kg} \mathrm{P}$ eq), marine eutrophication ( $\mathrm{kg} \mathrm{N} \mathrm{eq),}$ human toxicity (kg 1.4 DB (dichlorobenzene) eq), terrestrial ecotoxicity (kg 1.4 DB eq), freshwater ecotoxicity (kg 1.4 DB eq), marine ecotoxicity (kg 1.4 DB eq), and cumulative energy demand (MJ). As summarized in a review of published aquaculture LCA studies (Henriksson et al. 2012), global warming potential, acidification, and eutrophication are identified as three most frequently addressed impact categories in aquaculture and seafood LCA studies, followed by twelve less adopted impact categories (e.g. energy use, biotic resource use, human toxicity, and ecotoxicity). From an LCA perspective, the "human toxicity" and "terrestrial/marine/freshwater ecotoxicity" indicators reflect the potential impacts of a system on human health and ecosystem, rather than indicating the actual safety levels of products (Notarnicola et al. 2017). 


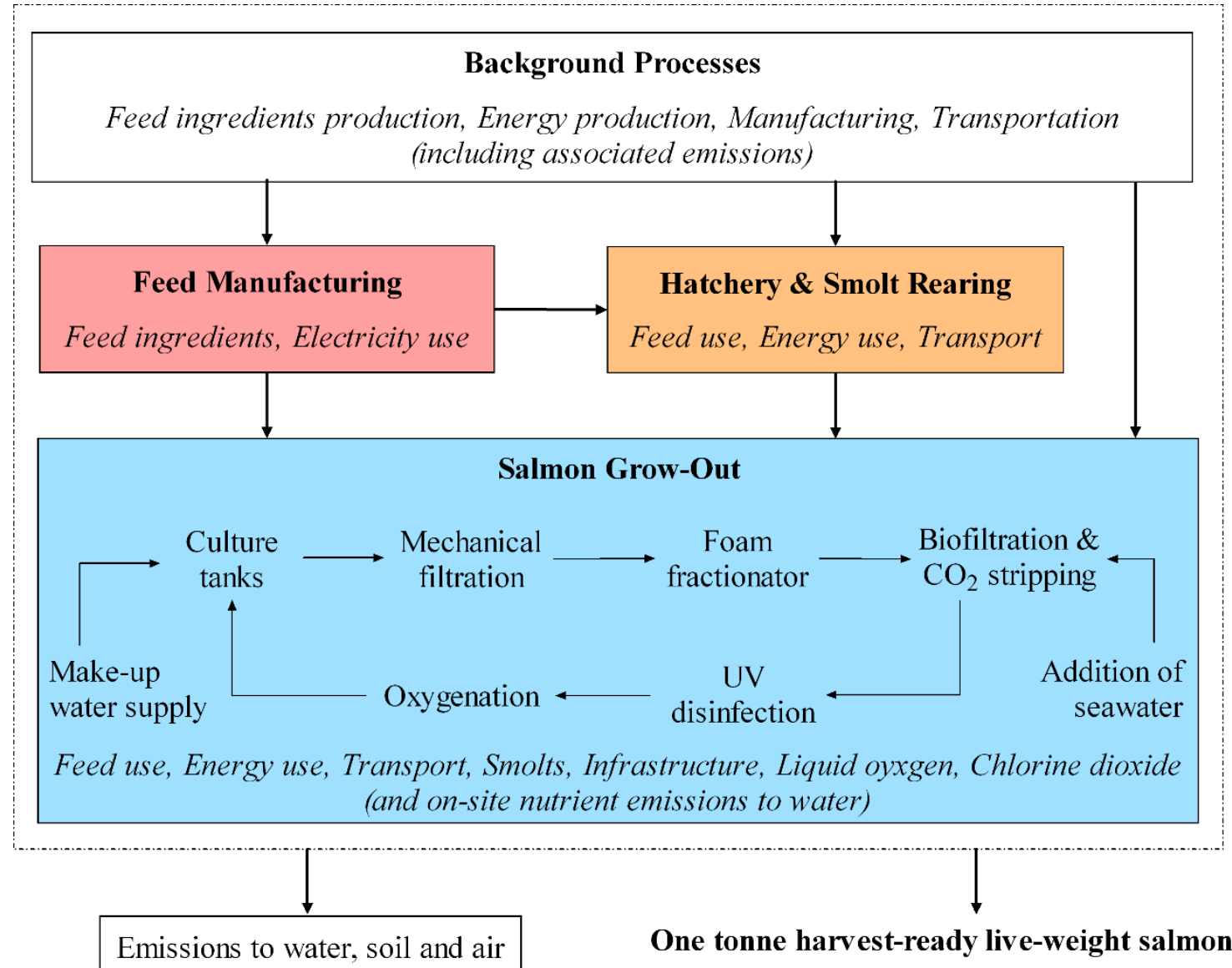

Figure 1 System boundaries for the cradle-to-farm gate LCA of the Atlantic salmon RAS farming

\subsubsection{Life cycle inventory}

The LCI phase involves the collection and compilation of all relevant input- and output-data of a defined system. The foreground (on-farm) material and energy use data came from the production data of the feed manufacturing plant, the hatchery $\&$ smolt rearing facility, and the salmon grow-out farm. In specific, the LCI data of the hatchery \& smolt rearing and feed manufacturing plants referred to their respective annual average production in 2015. The total and breakdown of electricity use at the hatchery \& smolt rearing and salmon grow-out farms were calculated based on the power rating and operational time of all equipment during the period under study. The LCI data of the salmon grow-out farm was based on a full grow-out period (15 months during December 2014 - February 2016), with a total production of 145 tonnes of live-weight salmon. During this grow-out period, twelve closed-containment systems (each having four rearing tanks and a total rearing volume of $500 \mathrm{~m}^{3}$ ) were operated in parallel.

Background data were taken from extensive LCI databases within SimaPro 8.3 software (see Table S3 in the Supporting Information available on the Web). Since the LCI databases in SimaPro contain only a few ready-to-use processes of feed ingredients, assumptions were made for missing feed ingredient production processes, as listed in Table S4 in the Supporting Information available on the Web.

On-site nutrient emissions from the salmon grow-out farm to water were estimated by means of a nutrient budget modeling approach (Aubin et al. 2006). In specific, the phosphorous (P) and nitrogen $(\mathrm{N})$ emissions were calculated based on nutrient balance analysis data from the grow-out farm studied. The solid form of $\mathrm{P} \& \mathrm{~N}$ in grow-out effluents referred to the respective nutrient in solid fish wastes collected from the mechanical filtration process. The dissolved $\mathrm{P} \& \mathrm{~N}$ referred to the respective nutrient in sludge discharged from the biofiltration process. At the time of this study, both the collected solid fish wastes and sludge were discharged into the adjunct sea. Further 
information on farm-level $\mathrm{P} \& \mathrm{~N}$ emissions to receiving water was provided in Table S5 in the Supporting Information available on the Web.

\subsection{3 life cycle impact assessment}

Life cycle impact assessment was performed using two LCIA methods available in the SimaPro v8.3 software, i.e. Cumulative Energy Demand v1.09 and ReCiPe v1.13. The Cumulative Energy Demand (CED) method aims to quantify the total ("cumulative") energy demand throughout the cradle-to-farm-gate Atlantic salmon production system. The ReCiPe method is the outcome of alignment between the midpoint-oriented CML 2002 method and the endpoint-oriented Eco-indicator 99 method (Goedkoop et al. 2013). Since the endpoint method (damage-oriented) has a relatively higher uncertainty (Goedkoop et al. 2013), the problem-oriented ReCiPe midpoint (H) v1.13 / World ReCiPe method was chosen for the other eight impact indicators assessed in this study. The abbreviation $\mathrm{H}$ stands for the ReCiPe hierarchist perspective, referring to the most common policy principles.

\subsubsection{Sensitivity, scenario, and uncertainty analyses}

The results of an LCA study can be sensitive to a variety of uncertainty sources, such as LCI data and assumptions made for lacking processes. In order to investigate how the life cycle impacts of the farmed salmon change with alternative LCI parameters, sensitivity analyses were conducted with focus on (i) stocking density (grow-out), (ii) economic feed conversion ratio (eFCR), and (iii) life expectancy of the grow-out infrastructure. Besides, scenario analyses were made to evaluate the potential implications of (i) substitutes of marine- and poultry-derived with crop-derived ingredients for feed production, and (ii) changes of electricity generation sources. In order to check the effects of various uncertainty sources on the modelled LCIA results, Monte Carlo simulation was executed in SimaPro, using 10000 runs to generate 95\% confidence intervals (Goedkoop et al. 2016).

\section{RESULTS}

\subsection{Life cycle inventory}

During the grow-out period, approximately 35000 Atlantic salmon smolts were transferred to the grow-out farm, with an average mass of 100 gram. Correspondingly, 29000 salmon were harvested with an average mass of 5 kilogram. This grow-out period had an approximate mortality rate of $13 \%$ and a culling rate of $4 \%$ (mostly male). The stocking density during the grow-out period was $24.2 \mathrm{~kg} / \mathrm{m}^{3}$ (cf. the farm's design stocking density is $45 \mathrm{~kg} / \mathrm{m}^{3}$ ). The eFCR of this grow-out period was 1.45 (eFCR $=\mathrm{kg}$ of feed distributed / $\mathrm{kg}$ of fish produced, including losses due to uneaten feed and fish mortalities). The calculated eFCR was slightly higher than the farm's empirical eFCR of 1.4, owing to slight overfeeding applied during this grow-out period. The calculated eFCR of the smolt rearing plant was 1.01, close to the plant's average eFCR of 1.0. The water use rate was $1862 \mathrm{~m}^{3}$ of seawater per tonne live-weight salmon during the grow-out phase, and $2000 \mathrm{~m}^{3}$ of freshwater per tonne smolt produced at the hatchery \& rearing facility. A summary of key LCI data is provided in Table S6 in the Supporting Information available on the Web.

The total on-site electricity use of the three foreground systems was $8420 \mathrm{kWh}$ per tonne live-weight salmon harvested, among which the salmon grow-out farm accounted for 89.2\% (7509 $\mathrm{kWh}$ ), the hatchery \& smolt rearing facility $5.6 \%(469 \mathrm{kWh})$, and the feed manufacturing plant $5.2 \%$ (442 kWh for feed milling). For the hatchery \& smolt rearing facility, the top three electricity users were water circulation pump (2.9\%), water-cooling (1.7\%), and freshwater supply pump (0.5\%). Remarkably, all top four electricity-intensive equipment were in the salmon grow-out farm, including water circulation pump (36.6\%), make-up water supply pump (22.1\%), UV lamp (16.5\%), 
and biofilter blowers (9.1\%). Since no monitoring data were available at the unit operational level, the breakdown of electricity use was calculated by means of the respective technical design data and operational time of the salmon grow-out/hatchery farms and feed milling equipment. Detailed on-site electricity use data appear in Table S7 in the Supporting Information available on the Web.

\subsection{Life cycle impact assessment}

The LCIA results of the Atlantic salmon RAS farming system are illustrated in Figure 2 (for details, see Tables S8 and S9 in the Supporting Information available on the Web). The on-site electricity use at the grow-out farm dominated six of the nine impact categories: marine ecotoxicity (MET, 52\%), freshwater ecotoxicity (FET, 51\%), climate change (CC, 46\%), freshwater eutrophication (FEU, 42\%), cumulative energy demand (CED, 40\%), and human toxicity (HT, $39 \%$ ). Feed production was the primary contributor to the impacts of terrestrial ecotoxicity (TET, 95\%) and terrestrial acidification (TA, 48\%). In this study, the feed production process includes both the foreground feed manufacturing (milling) process and all upstream (background) processes for production of feed ingredients. The marine eutrophication (MEU) impact was mostly related to the on-site nutrient emissions of the grow-out farm (87\%), followed by feed production (12\%). For CED, the top two contributors were grow-out electricity use (40\%) and feed production (37\%). Liquid oxygen contributed between $5 \%$ and $22 \%$ to all impact categories, with higher values observed in FEU (22\%), HT (16\%), MET (14\%), and FET (13\%). The grow-out infrastructure contributed $6-24 \%$ of seven impact categories, but very little to TET $(1.4 \%)$ and MEU $(0.5 \%)$. The contribution of transport (salmon feed) seems to be negligible to all impact categories (up to $3 \%$ ).

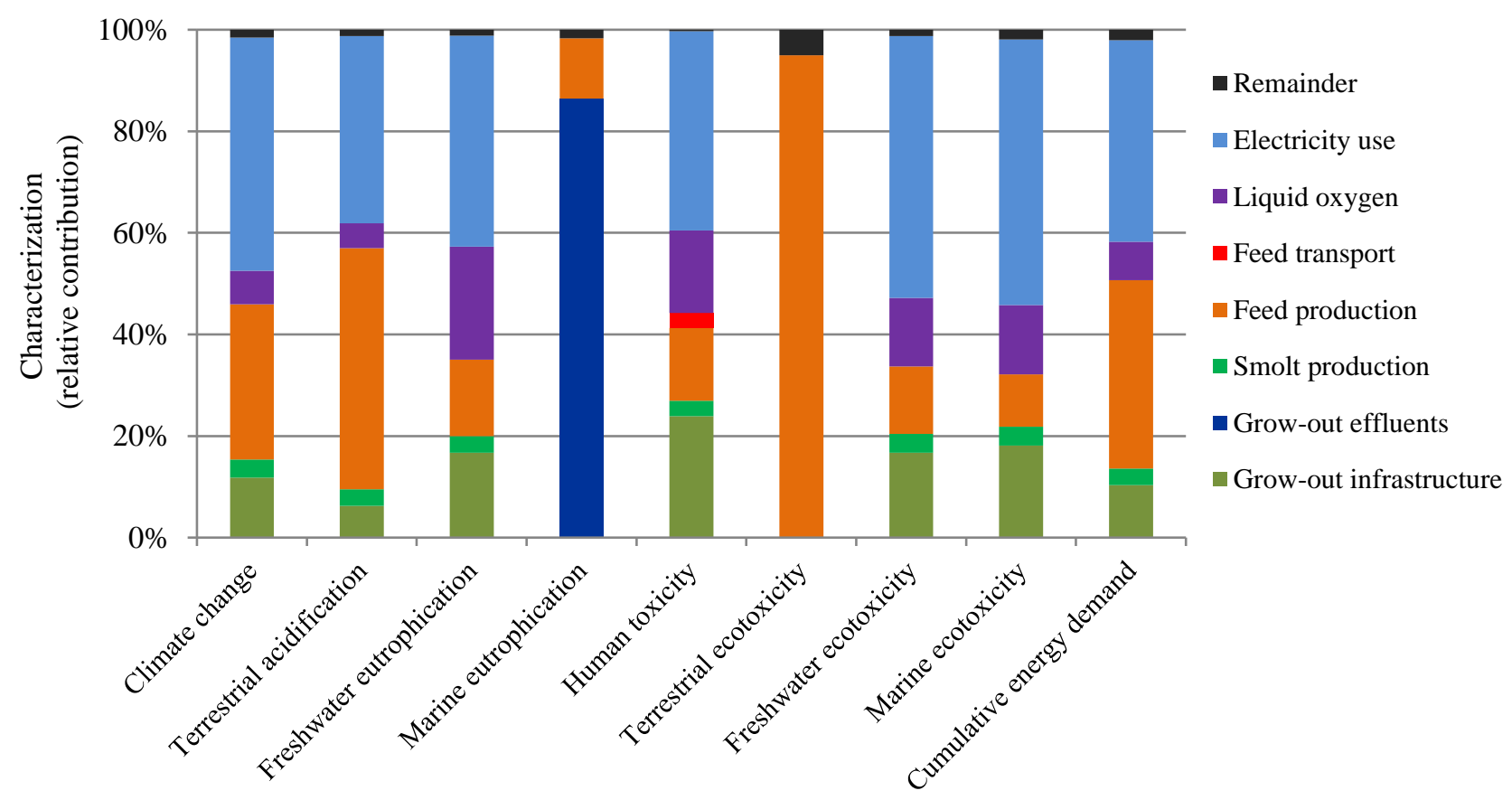

Figure 2 Life cycle contribution analysis of one tonne salmon harvested at the grow-out farm (cradle-to-farm gate) using the ReCiPe method. The term Remainder refers to the sum of processes each less than $2 \%$ of the total potential

Given the importance of salmon feed, contribution analysis of the cradle-to-gate life cycle impacts of feed production was performed (Figure 3; for details, see Table S10 and S11 in the Supporting Information available on the Web). Firstly, the marine ingredients (fish meal, fish oil, and krill meal) in total were the primary contributor to climate change $(\mathrm{CC}, 63 \%)$, terrestrial acidification (TA, 61\%), and cumulative energy demand (CED, 57\%), largely owing to diesel combusted in fishing vessel. In particular, krill meal contributed most to three impact categories, i.e. 
TA (40\%), CC (37\%), and CED (33\%). Secondly, the plant-based ingredients in total contributed mainly to TET (50\%, among which soybean meal $48 \%$ and maize gluten meal $2 \%$ ), MEU (32\%, among which wheat flour 24\% and soybean meal $8 \%$ ), and FET (17\%, among which soybean meal $14 \%$ and maize gluten meal 3\%). Thirdly, electricity use for feed milling contributed mainly to four impact categories: MET (29\%), FET (23\%), HT (16\%), and freshwater eutrophication (FEU, 16\%).

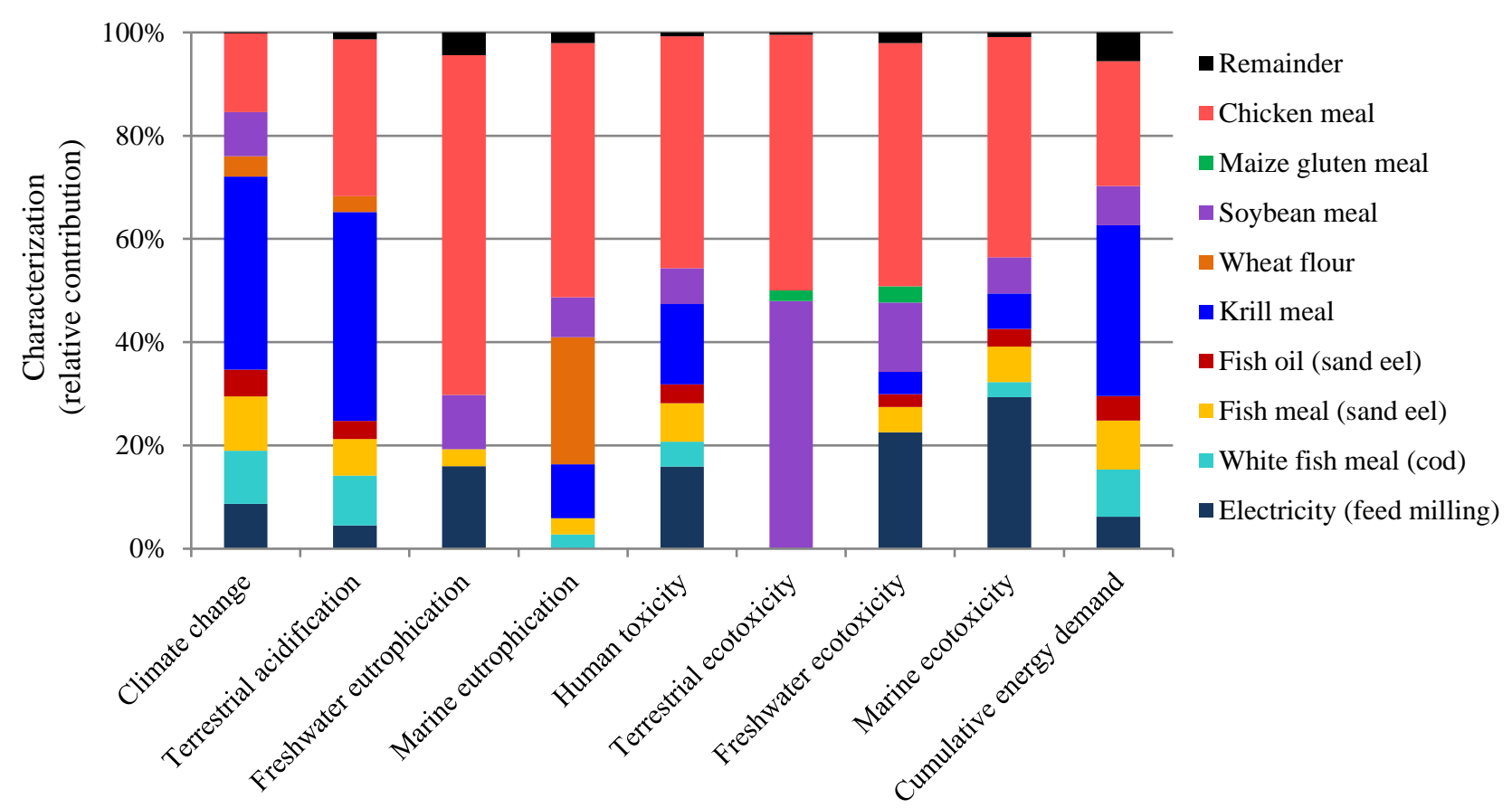

Figure 3 Life cycle contribution analysis of one tonne salmon feed product using the ReCiPe method (cradle-to-gate, excluding infrastructure and transportation requirements of the feed milling plant). The term Remainder refers to the sum of processes each less than $2 \%$ of the total potential

Among the feed ingredients used for feed production (Figure 3), chicken meal (only 5\% of the salmon feed on a dry-weight basis) dominated six of the nine impact categories assessed, including FEU (66\%), TET (50\%), MEU (49\%), FET (47\%), HT (45\%), and MET (43\%). This was mainly owing to electricity generation and poultry feed production for broiler chicken farms. For the FEU impact $(66 \%)$, results of specification per process showed that spoil from lignite mining and hard coal mining and for electricity generation accounted for $21 \%$ and $16 \%$, respectively, followed by the production of maize grain (10\%) and emissions from chicken farms (6\%). For the TET impact, results of specification per substance indicated that soil-borne emissions of cypermethrin (as an insecticide) and atrazine (as an herbicide) accounted for $32 \%$ and $10 \%$, respectively, out of the total contribution of $50 \%$.

\subsection{Sensitivity, scenario, and uncertainty analyses}

Table 1 presents the relative changes of the life cycle impacts per tonne live-weight salmon with alternative LCI parameters and scenarios on feed ingredients and electricity generation sources, compared to the baseline. For a detailed explanation of the selection of sensitivity and scenario analysis parameters and the modelling results, see Section 8 of the Supporting Information available on the Web. The results showed that the life cycle impacts per tonne live-weight salmon were most sensitive to the stocking density of the grow-out farm, following by changes of electricity generation sources, feed ingredients, eFCR and life expectancy of infrastructure. When increasing the stocking density from $24.2 \mathrm{~kg} / \mathrm{m}^{3}$ to $45 \mathrm{~kg} / \mathrm{m}^{3}$, the life cycle impacts per tonne salmon reduced by $20-35 \%$ in seven of the nine impact categories (except MEU and TET), while the life cycle impacts were similar between the stocking density of $45 \mathrm{~kg} / \mathrm{m}^{3}$ and $60 \mathrm{~kg} / \mathrm{m}^{3}$. Regarding the 
electricity generation scenarios on replacing $20 \%$ of coal-based (baseline) with wind- (S1) and nuclear-based (S2) electricity, respectively, the results showed that S1 and S2 had a similar trend in six impact categories, namely a reduction by $8-15 \%$ in CC, TA, FE and HT while up to $0.5 \%$ in MEU and TET.

The effect of uncertainty sources on the respective life cycle impacts per tonne salmon and feed was estimated using Monte Carlo uncertainty analysis in SimaPro v8.3 (Table S12 in the Supporting Information available on the Web). Regarding the life cycle impacts per tonne live-weight salmon, marine eutrophication $(\mathrm{CV}=0.9 \%)$ had a lowest level of uncertainty and human toxicity $(\mathrm{CV}=93 \%)$ had a highest level of uncertainty. For the life cycle impacts per tonne salmon feed, a lower level of uncertainty was in climate change and terrestrial acidification $(\mathrm{CV}=3 \%)$, while a higher level of uncertainty existed in human toxicity $(\mathrm{CV}=42 \%)$ and freshwater eutrophication $(\mathrm{CV}=35 \%)$. It is noted that the results of absolute uncertainties of Monte Carlo analysis in SimaPro currently take into account only the uncertainty in life cycle inventory, without considering the uncertainties in the characterization scores themselves (Goedkoop et al. 2016). The results of this Monte Carlo analysis using SimaPro, therefore, can be interpreted as an indicator of the relative uncertainty in each impact category.

Table 1 Sensitivity and scenario analyses for life cycle impacts per tonne live-weight salmon, including the relative change (\%) compared to the baseline

\begin{tabular}{|c|c|c|c|c|c|c|c|c|c|}
\hline LCI parameters & $\begin{array}{l}\mathrm{CC} \\
(\%) \\
\end{array}$ & $\begin{array}{l}\text { TA } \\
(\%)\end{array}$ & $\begin{array}{c}\text { FEU } \\
(\%) \\
\end{array}$ & $\begin{array}{c}\text { MEU } \\
(\%)\end{array}$ & $\begin{array}{l}\mathrm{HT} \\
(\%) \\
\end{array}$ & $\begin{array}{l}\text { TET } \\
(\%) \\
\end{array}$ & $\begin{array}{r}\text { FET } \\
(\%) \\
\end{array}$ & $\begin{array}{c}\text { MET } \\
(\%) \\
\end{array}$ & $\begin{array}{c}\text { CED } \\
(\%) \\
\end{array}$ \\
\hline \multicolumn{10}{|l|}{ Sensitivity analysis } \\
\hline \multicolumn{10}{|l|}{ Stocking density (grow-out) } \\
\hline $\mathrm{S} 1: 45 \mathrm{~kg} / \mathrm{m}^{3}$ & -27.7 & -20.7 & -30.1 & -1.1 & -31.5 & -1.1 & -33.5 & -34.5 & -24.2 \\
\hline $\mathrm{S} 2: 60 \mathrm{~kg} / \mathrm{m}^{3}$ & -27.9 & -20.4 & -30.7 & -1.1 & -33.4 & -1.3 & -34.1 & -35.2 & -24.4 \\
\hline \multicolumn{10}{|l|}{ Economic feed conversion ratio } \\
\hline $\mathrm{S} 1: \mathrm{eFCR}=1.3$ & -3.1 & -4.9 & -1.5 & -9.9 & -1.5 & -9.7 & -1.4 & -1.1 & -3.8 \\
\hline $\mathrm{S} 2: \mathrm{eFCR}=1.1$ & -7.3 & -11.4 & -3.6 & -23.3 & -3.4 & -22.8 & -3.4 & -2.5 & -8.9 \\
\hline \multicolumn{10}{|l|}{ Life expectancy of infrastructure } \\
\hline S1: 10-year & +5.9 & +3.1 & +8.4 & +0.2 & +11.9 & +0.7 & +8.4 & +9.1 & +5.2 \\
\hline S2: 20-year & -3.0 & -1.6 & -4.2 & -0.1 & -6.1 & -0.4 & -4.2 & -4.6 & -2.6 \\
\hline \multicolumn{10}{|l|}{ Scenario analysis } \\
\hline \multicolumn{10}{|l|}{ Feed ingredients } \\
\hline $\begin{array}{l}\text { S1: substitute krill meal ( } 8 \%) \text { with } \\
\text { soybean meal }\end{array}$ & -9.8 & -19.1 & +1.0 & -1.2 & -1.6 & +30.8 & +0.6 & -0.2 & -10.4 \\
\hline $\begin{array}{l}\mathrm{S} 2 \text { : substitute chicken meal }(5 \%) \\
\text { with soybean meal }\end{array}$ & -3.6 & -14.4 & -9.4 & -10.3 & -6.1 & -28.4 & -5.6 & -4.2 & -7.7 \\
\hline \multicolumn{10}{|l|}{ Electricity generation sources } \\
\hline S1: replace $20 \%$ coal with wind & -14.6 & -11.8 & -12.0 & -0.5 & -8.2 & -0.1 & +9.0 & +7.8 & -7.1 \\
\hline S2: replace $20 \%$ coal with nuclear & -14.7 & -12.0 & -13.5 & -0.4 & -10.1 & -0.2 & -13.8 & -13.9 & +0.9 \\
\hline
\end{tabular}

Note. CC, climate change; TA, terrestrial acidification; FEU, freshwater eutrophication; MEU, marine eutrophication; HT, human toxicity; TET, terrestrial ecotoxicity; FET, freshwater ecotoxicity; MET, marine ecotoxicity; CED, cumulative energy demand.

\section{DISCUSSION}

\subsection{Environmental performance of farmed salmonid fish}

In order to better understand the life cycle inventory of Atlantic salmon farmed in the indoor RAS farm (hereafter referred to as the Chinese case), a comparison was made with three respective salmonid fish farming literature on (i) Atlantic salmon in a conceptual land-based RAS in the USA and open net-pen system in Norway (Liu et al. 2016), (ii) Chinook salmon in a pilot marine floating confined tank in Canada (McGrath et al. 2015), and (iii) Atlantic salmon in a land-based, 
flow-through system and Arctic char in a recirculating system in Canada (Ayer and Tyedmers 2009) (Table S13 in the Supporting Information available on the Web).

For simplification purposes, this comparison addressed only six grow-out operational parameters, including stocking density, production losses, farm-level electricity use, liquid oxygen consumption, eFCR, and on-site nutrient emissions. The comparison showed a substantial variance among the LCI data of different salmonid fish farming systems. Take the on-site electricity use as an example. Compared to the concept-level salmon RAS farming in the USA with a maximum stocking density of $80 \mathrm{~kg} / \mathrm{m}^{3}$ and eFCR of 1.09 (Liu et al. 2016), electricity use in the Chinese case (eFCR 1.45) increased by $38 \%$ at the baseline stocking density of $24.2 \mathrm{~kg} / \mathrm{m}^{3}$ and decreased by $20 \%$ at the design stocking density of $45 \mathrm{~kg} / \mathrm{m}^{3}$. According to the electricity use data reported by Ayer and Tyedmers (2009), the Chinese case (baseline) accounted for 56\% of the land-based, flow-through Atlantic salmon farm (stocking density $38 \mathrm{~kg} / \mathrm{m}^{3}$, eFCR 1.17) and $33 \%$ of the recirculating Arctic char farm (stocking density $73 \mathrm{~kg} / \mathrm{m}^{3}$, eFCR 1.45) in Canada. Regarding the on-site nutrient emissions to water, the total $\mathrm{N}$ and $\mathrm{P}$ emissions per tonne salmon of the Chinese case was close to the value reported in the offshore closed-containment case in Canada (McGrath et al. 2015), since the grow-out farm in China currently discharged all collected nutrients to the sea.

The contribution analysis of this cradle-to-farm gate LCA study (Figure 2) confirmed previous results in the literature on the importance of feed production (and on-site energy use in the case of closed-containment systems) to the life cycle impacts of farmed salmon. Based on the average life cycle impacts of open net-pen farmed salmon in Norway, UK, Canada and Chile, for example, Pelletier et al. (2009) reported that feed accounted for $94 \%$ of global warming and acidifying emissions, and $93 \%$ of cumulative energy use, while farm-level energy use contributed to $4 \%$ of cumulative energy use, $3 \%$ of global warming, and acidifying emissions (3\%). In an LCA of the actual production cycle of Chinook salmon farmed in an offshore closed-containment system, McGrath et al. (2015) concluded that feed production was the primary contributor of global warming (60\%) and acidification potential (57\%), while the on-site energy use contributed mostly to cumulative energy use (42\%). Similarly, this Chinese case study demonstrated that on-site electricity use and feed production dominated eight (ranging 54-95\% in total) of the nine impact categories assessed, except the marine eutrophication impact.

This study indicated that the contribution of infrastructure needs further investigation in future LCA studies on land-based RAS farming. Previous aquaculture LCA studies either excluded infrastructure or reported it with little contribution to the life cycle impacts of recirculating fish production systems. For instance, Aubin et al. (2009) presented that infrastructure contributed between $0 \%$ and $5 \%$ to the overall cradle-to-farm gate life cycle impacts per tonne live-weight turbot in a French recirculating farm. In an LCA of Chinook salmon farmed in an offshore closed-containment system in Canada, by contrast, McGrath et al. (2015) reported relatively higher contributions of infrastructure (mainly a cylindrical tank made of steel and thermoplastics, 20-year life expectancy) to climate change (7-12\%), acidification potential (5-8\%), and cumulative energy demand (6-10\%). For comparison, this indoor salmon RAS study (Figure 2) illustrated that the grow-out infrastructure (with a 15-year life expectancy) contributed to human toxicity (24\%), marine ecotoxicity (18\%), freshwater ecotoxicity (17\%), freshwater eutrophication (17\%), climate change (12\%), cumulative energy demand (10\%), and terrestrial acidification (6\%). Limitations of the present study are briefly discussed in Section 10 in the Supporting Information available on the Web.

\subsection{Strategies for improving environmental performance of indoor salmon RAS farming}

Environmental hotspots of a life cycle can serve as a basis for developing mitigation measures and strategies toward more eco-friendly salmon production. For the indoor salmon RAS case in this 
study, feed production, grow-out effluents, and on-site electricity use were identified as main environmental hotspots of the cradle-to-farm gate salmon production system.

Three feed-related issues (grow-out nutrient emissions, eFCR, and feed ingredient production) play a key role in minimizing the life cycle impacts per tonne salmon harvested at the grow-out farm. Toward more sustainable salmon production in RAS, on one hand, it is crucial to regulating nutrient loading of grow-out effluents discharged to the sea, so as to minimize the potential marine eutrophication impact. The collected solid wastes and sludge from the mechanical \& biological filtration processes could be used as, for instance, a source of biogas (after anaerobic composting), agriculture fertilizers, and an input in microalgae production (Campo et al. 2010). On the other hand, a lower eFCR could reduce the life cycle impacts of feed as well as the eutrophication potential of grow-out effluents. The sensitivity analysis results (Table 1) demonstrated that, compared to the baseline eFCR of 1.45, the marine eutrophication potential decreased by $10 \%$ at the eFCR of 1.3 and by $23 \%$ at the eFCR of 1.1. However, appropriate feeding regimes and eFCR in practice depend on a number of interrelated factors, particularly on feed composition, feed digestibility and stability, feeding technology and strategies, fish growth and size, and mortality (Pelletier et al. 2009).

Owing to concerns on overfishing and increasing costs, there have been many efforts to substitute marine protein and fat with plant-based ingredients in production of salmonid feeds (Davidson et al. 2016; Trullàs et al. 2015). From an ecological sustainability perspective, it is preferable to produce salmon feed using ingredients with lower environmental impacts, given that eFCR remains similar during the grow-out period. However, environmental trade-offs across impact categories may emerge from substitution of marine ingredients with plant-derived ingredients, as seen from Table S11 in the Supporting Information available on the Web. Compared to the life cycle impacts per tonne soybean meal, this study showed that (i) 1 tonne krill meal was 2-50 times higher in five impact categories (TA, CC, CED, HT, and MEU) and lower by a factor of 0.1-5 in three categories (FET, FEU, and TET), and (ii) 1 tonne sand eel-based fishmeal was 2.4 times higher in TA but lower by a factor of 0.01-5 in the other eight categories. It is noted that this streamlined LCA analysis (Table S11) did not consider the differences in the protein and lipid content of alternative feed ingredients, which are important for feed production. In an LCA of aquafeed ingredients, for instance, Silva et al. (2018) reported that the production of lipid ingredients required more mass of the ingredient source-component.

On-site electricity use was identified as one main environmental hotspot of the studied salmon RAS farming system, owing to the following two reasons. Firstly, the RAS technology is currently energy-intensive. Ensuring a continuous water flow is crucial to avoiding system failure for any fish farm depending on a piped water supply (Chadwick et al. 2010). In this case study, more than half of the total on-site electricity was used by pumps for water circulation (37\%) and water supply (22\%) during the grow-out period. Compared to the operational stocking density of $24.2 \mathrm{~kg} / \mathrm{m}^{3}$, however, the farm-level electricity use per tonne salmon could decrease by $46 \%$ at the design stocking density of $45 \mathrm{~kg} / \mathrm{m}^{3}$ (see Table S13 in section 9 of supporting information on the Web). Besides optimization of operational stocking density, a further reduction of the farm-level electricity use per tonne harvested salmon largely depends on the development of energy-efficient pumps and the reduction of unit-level energy consumption. Secondly, an alternative solution for fish farms would be to generate on-site renewable electricity, such as solar and wind power (if applicable), since a substantial change in country electricity mix may take a long time.

It is interesting to notice that the life cycle impacts per tonne farmed salmon in RAS, to some extent, were sensitive to stocking density of grow-out rearing tanks (Table 1). Since the indoor recirculating systems require relatively high initial capital investments, RAS farming with high stocking densities and yields are expected to offset investment costs (Martins et al. 2010). In a 10-week stress-oriented experiment conducted at the same salmon RAS farm, Liu et al. (2015) reported that the growth rate of 14-month-old post-smolts decreased by $1.6 \%$ at medium-density $\left(15.1-31.1 \mathrm{~kg} / \mathrm{m}^{3}\right.$, initial to final density) and by $3.8 \%$ at high-density $\left(30.2-61.3 \mathrm{~kg} / \mathrm{m}^{3}\right)$, compared 
to low-density $\left(7.6-15.7 \mathrm{~kg} / \mathrm{m}^{3}\right)$, while different stocking densities had no influence on the mortality rate. In this regard, an integrated assessment of the salmon RAS production system is needed in future studies to find win-win solutions between operational performance (such as stocking density, water quality, energy use) and fish welfare (condition/quality) in particular.

\subsection{Promoting LCA as a decision support tool for environmental assessment of aquaculture}

On the path toward more sustainable aquaculture, life cycle thinking and life cycle approaches should be employed in aquaculture environmental management and decision-making. In particular, life cycle thinking aims to extend the traditional focus of environmental engineering on production site to assess the potential environmental impacts of a product throughout the whole value chain.

Although LCA has been regarded as the most mature life-cycle based environmental systems analysis method to aid in addressing environmental sustainability challenges (Curran 2015), two aspects deserve further attention for the application of LCA in aquaculture. Firstly, aquaculture LCA studies need to obtain representative, precise and preferably site-specific data for both foreground and background processes. The currently available LCI databases (such as ecoinvent v3, LCA food DK, and Agri-footprint) have only a few aquaculture-related background processes from different geographic regions. There have been efforts to improve the LCI databases of aquafeed production, such as the reported LCI data of three Peruvian fishmeal plants (Fréon et al. 2017). However, there are still very few publications on LCI of feed ingredient production and feed manufacturing processes in China. To reduce uncertainties associated with results of aquaculture LCA studies, it is crucial to having a further update on aquaculture-related LCI database, particularly on fisheries, livestock and agriculture production, and processing of feed ingredients in highly relevant regions.

Secondly, aquaculture LCIA results need to be interpreted with caution, especially in the case of comparing the environmental impacts of different fish farming systems. Although LCA has a wide application in land-based products and production processes, a number of aquaculture-specific impacts have not yet been fully considered in LCIA (Samuel-Fitwi et al. 2012), e.g. related to spread of diseases and salmon lice, impacts of trawling on seafloor, effects of escaped salmon on ecosystems, use of medicines and antibiotics, antifouling, and overfishing (Ellingsen and Aanondsen 2006; Ellingsen et al. 2009). It therefore becomes very hard to make a fair comparison of the life cycle impacts of fish products e.g. between land-based RAS and marine cage aquaculture, even if the same LCIA method employed in an LCA study. In order to better address those aquaculture specific environmental impacts in LCIA, multidisciplinary cooperation is needed between LCA practitioners, LCA developers, environmental and ecological modelers, and aquaculture experts.

\section{CONCLUSIONS}

This paper presented the results of LCI and LCIA per tonne harvest-ready live-weight Atlantic salmon (Salmo salar) in an indoor RAS farm, located in northern China. To our knowledge, this study is the first comprehensive, multi-impact category LCA of Atlantic salmon farmed in indoor RAS at commercial scale in the world. It provided a broad overview of the ecological challenges of moving offshore salmon fish farming toward land-based production. The LCIA results, based on the ReCiPe midpoint $(\mathrm{H})$ and Cumulative Energy Demand methods, showed that (i) feed production was the primary contributor to the impacts of terrestrial ecotoxicity (95\%) and terrestrial acidification (48\%), (ii) the on-site nutrient emissions from the grow-out farm contributed most to the marine eutrophication impact (87\%), and (iii) the farm-level electricity use dominated the other six impact categories, ranging between $39 \%$ (human toxicity) to 52\% (marine ecotoxicity). For the life cycle impacts per tonne salmon feed, krill meal (8\%) contributed most to terrestrial acidification (40\%), climate change (37\%), and cumulative energy demand (34\%), while chicken meal (5\%) 
dominated the other six impact categories (43-65\%). In particular, the life cycle impacts per tonne live-weight salmon seemed sensitive to stocking density of the grow-out farm. Results of the sensitivity analysis indicated that the life cycle impacts per tonne salmon reduced by $20-35 \%$ in seven of the nine impact categories (except marine eutrophication and terrestrial ecotoxicity) when the stocking density increased from $24.2 \mathrm{~kg} / \mathrm{m}^{3}$ (operational data of the period studied) to $45 \mathrm{~kg} / \mathrm{m}^{3}$ (design data of this grow-out farm).

Results of the present study would be useful for enhancing understanding of the environmental performance of farmed salmon in indoor RAS at commercial scale, and serve as a basis for developing LCA-based innovations toward more eco-friendly farmed salmon. In the development of strategies and mitigation measures toward more sustainable aquaculture production from an LCA perspective, this study also indicates that it is important (i) to analyze the relative contribution of respective mitigation measures to the overall life cycle impacts of a system for identifying priority strategies, and (ii) to check trade-offs between impact categories and among alternative measures for avoiding a shift of environmental problems. Without LCA, environmental improvement measures of a farm may be suboptimal and cause unintended environmental problem shifting. To promote the application of LCA as an environmental decision support tool in the aquaculture industry, future research should focus on improving the currently underdeveloped aquaculture-related LCI database and addressing aquaculture specific environmental impacts in life cycle impact assessment.

\section{ACKNOWLEDGEMENTS}

The authors gratefully acknowledge Dr. Guoxiang Sun for help with collection of production data on the Atlantic salmon RAS farm in China as well as three anonymous reviewers commissioned by the journal for their helpful comments.

\section{REFERENCES}

Aubin, J., E. Papatryphon, H. M. G. van der Werf, and S. Chatzifotis. 2009. Assessment of the environmental impact of carnivorous finfish production systems using life cycle assessment. Journal of Cleaner Production 17(3): 354-361.

Aubin, J., E. Papatryphon, H. M. G. Van der Werf, J. Petit, and Y. M. Morvan. 2006. Characterisation of the environmental impact of a turbot (Scophthalmus maximus) re-circulating production system using Life Cycle Assessment. Aquaculture 261(4): 1259-1268.

Ayer, N. W. and P. H. Tyedmers. 2009. Assessing alternative aquaculture technologies: life cycle assessment of salmonid culture systems in Canada. Journal of Cleaner Production 17(3): 362-373.

Bergheim, A., A. Drengstig, Y. Ulgenes, and S. Fivelstad. 2009. Production of Atlantic salmon smolts in Europe-Current characteristics and future trends. Aquacultural Engineering 41(2): 46-52.

Bohnes, F.A. and A. Laurent. 2018. LCA of aquaculture systems: methodological issues and potential improvements. The International Journal of Life Cycle Assessment. In press. https://doi.org/10.1007/s11367-018-1517-x.

Campo, L. M. D., P. Ibarra, X. Gutierrez, and H. Takle. 2010. Utilization of sludge from recirculating aquaculture systems. Nofima Project report 9/2010. Tromsø: Nofima.

Cao, L., J. S. Diana, and G. A. Keoleian. 2013. Role of life cycle assessment in sustainable aquaculture. Reviews in Aquaculture 5(2): 61-71.

Chadwick, E. M. P., G. J. Parsons, and B. Sayavong, eds. 2010. Evaluation of Closed-containment Technologies for Saltwater Salmon Aquaculture. Ottawa, Canada: NRC Research Press.

Curran, M. A., ed. 2015. Life cycle assessment student handbook. Massachusetts: Scrivener Publishing LLC.

Dalsgaard, J., I. Lund, R. Thorarinsdottir, A. Drengstig, K. Arvonen, and P. B. Pedersen. 2013. Farming different species in RAS in Nordic countries: Current status and future perspectives. Aquacultural Engineering 53: 2-13.

Davidson, J., F. T. Barrows, P. B. Kenney, C. Good, K. Schroyer, and S. T. Summerfelt. 2016. Effects of feeding a fishmeal-free versus a fishmeal-based diet on post-smolt Atlantic salmon Salmo salar 
performance, water quality, and waste production in recirculation aquaculture systems. Aquacultural Engineering 74: 38-51.

Diana, J. S., H. S. Egna, T. Chopin, M. S. Peterson, L. Cao, R. Pomeroy, M. Verdegem, W. T. Slack, M. G. Bondad-Reantaso, and F. Cabello. 2013. Responsible Aquaculture in 2050: Valuing Local Conditions and Human Innovations Will Be Key to Success. BioScience 63(4): 255-262.

Ebeling, J. M. and M. B. Timmons. 2012. Recirculating Aquaculture Systems. In Aquaculture Production Systems, edited by J. H. Tidwell. Chichester: Wiley-Blackwell.

Ellingsen, H. and S. A. Aanondsen. 2006. Environmental Impacts of Wild Caught Cod and Farmed Salmon A Comparison with Chicken. The International Journal of Life Cycle Assessment 11(1): 60-65.

Ellingsen, H., J. O. Olaussen, and I. B. Utne. 2009. Environmental analysis of the Norwegian fishery and aquaculture industry-A preliminary study focusing on farmed salmon. Marine Policy 33(3): 479-488.

FAO (Food and Agriculture Organization of the United Nations), 2016. The State of World Fisheries and Aquaculture 2016. Rome: Food and Agriculture Organization of the United Nations.

Fréon, P., H. Durand, A. Avadí, S. Huaranca, and R.O. Moreyra. 2017. Life cycle assessment of three Peruvian fishmeal plants: Toward a cleaner production. Journal of Cleaner Production 145: 50-63.

Goedkoop, M., R. Heijungs, M. Huijbregts, A. D. Schryver, J. Struijs, and R. van Zelm. 2013. ReCiPe 2008: a life cycle impact assessment method which comprises harmonized category indicators at the midpoint and the endpoint level. Report I: Characterisation. The Hague: Ministry of Housing, Spatial Planning and Environment.

Goedkoop, M., M. Oele, J. Leijting, T. Ponsioen, and E. Meijer. 2016. Introduction to LCA with SimaPro. SimaPro report. Utrecht: PRé Sustainability.

Henriksson, P. J. G., J. B. Guinée, R. Kleijn, and G. R. de Snoo. 2012. Life cycle assessment of aquaculture systems - a review of methodologies. The International Journal of Life Cycle Assessment 17(3): 304-313.

HLPE (The High Level Panel of Experts on Food Security and Nutrition). 2014. Sustainable fisheries and aquaculture for food security and nutrition. Rome: UN Committee on World Food Security.

ISO (International Organization for Standardization). 2006. ISO 14040: Environmental management - Life cycle assessment - Principles and framework. Geneva: International Organization for Standardization.

Iversen, A., Q. Andreassen, Ø. Hermansen, T.A. Larsen, and B.F. Terjesen. 2013. Oppdrettsteknologi og konkurranseposisjon ("Farming Technology and competition position", in Norwegian). Nofima report 32/2013. Tromsø: Nofima.

Lekang, O. I., C. Salas-Bringas, and J. C. Bostock. 2016. Challenges and emerging technical solutions in on-growing salmon farming. Aquaculture International 24(3): 757-766.

Liu, B., Y. Liu, and X. Wang. 2015. The effect of stocking density on growth and seven physiological parameters with assessment of their potential as stress response indicators for the Atlantic salmon (Salmo salar). Marine and Freshwater Behaviour and Physiology 48(3): 177-192.

Liu, Y., T. W. Rosten, K. Henriksen, E. S. Hognes, S. Summerfelt, and B. Vinci. 2016. Comparative economic performance and carbon footprint of two farming models for producing Atlantic salmon (Salmo salar): Land-based closed containment system in freshwater and open net pen in seawater. Aquacultural Engineering 71: 1-12.

Martins, C. I. M., E. H. Eding, M. C. J. Verdegem, L. T. N. Heinsbroek, O. Schneider, J. P. Blancheton, E. R. d'Orbcastel, and J. A. J. Verreth. 2010. New developments in recirculating aquaculture systems in Europe: A perspective on environmental sustainability. Aquacultural Engineering 43(3): 83-93.

McGrath, K. P., N. L. Pelletier, and P. H. Tyedmers. 2015. Life Cycle Assessment of a Novel Closed-Containment Salmon Aquaculture Technology. Environmental Science \& Technology 49(9): 5628-5636.

Notarnicola, B., S. Sala, A. Anton, S.J. McLaren, E. Saouter, and U. Sonesson. 2017. The role of life cycle assessment in supporting sustainable agri-food systems: A review of the challenges. Journal of Cleaner Production 140(2): 399-409.

Papatryphon, E., J. Petit, S. J. Kaushik, and H. M. van der Werf. 2004. Environmental impact assessment of salmonid feeds using Life Cycle Assessment (LCA). Ambio 33(6): 316-323.

Pawlowski, J., P. Esling, F. Lejzerowicz, T. Cordier, J. A. Visco, C. I. M. Martins, A. Kvalvik, K. Staven, and T. Cedhagen. 2016. Benthic monitoring of salmon farms in Norway using foraminiferal metabarcoding. Aquaculture Environment Interactions 8: 371-386.

Pelletier, N., P. Tyedmers, U. Sonesson, A. Scholz, F. Ziegler, A. Flysjo, S. Kruse, B. Cancino, and H. Silverman. 2009. Not All Salmon Are Created Equal: Life Cycle Assessment (LCA) of Global Salmon Farming Systems. Environmental Science \& Technology 43(23): 8730-8736. 
Samuel-Fitwi, B., S. Wuertz, J. P. Schroeder, and C. Schulz. 2012. Sustainability assessment tools to support aquaculture development. Journal of Cleaner Production 32: 183-192.

Silva, C.B., L.M.P. Valente, E. Matos, M. Brandão, and B. Neto. 2018. Life cycle assessment of aquafeed ingredients. The International Journal of Life Cycle Assessment 23(5): 995-1017.

Sonesson, U., J. Berlin, and F. Ziegler. eds. 2010. Environmental assessment and management in the food industry: life cycle assessment and related approaches. Cambridge: Elsevier.

Trullàs, C., R. Fontanillas, A. Tres, and R. Sala. 2015. Vegetable re-esterified oils in diets for rainbow trout: Effects on fatty acid digestibility. Aquaculture 444: 28-35.

World Bank. 2013. Fish to 2030: Prospects for Fisheries and Aquaculture. World Bank report number 83177-GLB. Washington DC: The World Bank.

Ziegler, F., S. Hornborg, B. S. Green, O. R. Eigaard, A. K. Farmery, L. Hammar, K. Hartmann, S. Molander, R. W. R. Parker, E. Skontorp Hognes, I. Vázquez-Rowe, and A. D. M. Smith. 2016. Expanding the concept of sustainable seafood using Life Cycle Assessment. Fish and Fisheries 17(4): 1073-1093. 


\section{SUPPORTING INFORMATION FOR:}

Song, X., Y. Liu, J. B. Pettersen, M. Brandão, X. Ma, S. Røberg, and B. Frostell. 2019. Life Cycle Assessment of recirculating aquaculture systems: A case of Atlantic salmon farming in China. Journal of Industrial Ecology.

\section{Summary}

This supporting information provides the following supplementary information. Section 1 presents a brief summary of published LCA studies on salmonid aquaculture systems (Table S1). Section 2 describes the recirculating Atlantic salmon grow-out farm, the hatchery \& smolt rearing facility, the salmon feed manufacturing plant, and detailed formulations of feed product (Table S2). Section 3 details background data sources (Table S3) and assumptions made for LCI analysis of feed ingredient production processes (Table S4). Section 4 explains the results of nutrient mass-balance modelling for 1 tonne harvest-ready live-weight salmon at the grow-out farm (Table S5). Section 5 provides LCI analysis results of the three foreground systems studied (Table S6). Section 6 lists a breakdown of on-site electricity use to produce 1 tonne live-weight salmon (Table S7). Section 7 gives the results of life cycle impact assessment with regard to per tonne live-weight Atlantic salmon at the grow-out farm (Tables S8-S9), per tonne salmon feed product (Table S10), and per tonne specific feed ingredient (Table S11). Section 8 shows the results of sensitivity, scenario and uncertainty analyses (Table S12). Section 9 demonstrates a comparison of the grow-out LCI data between this study and the selected literature (Table S13). Section 10 reports limitations of the present study. 


\section{Section 1: Summary of published LCA studies on salmonid aquaculture systems}

Table S1 Summary of published LCA studies on salmonid aquaculture systems

\begin{tabular}{|c|c|c|c|c|c|c|c|}
\hline \multicolumn{3}{|l|}{ General } & \multirow{2}{*}{$\begin{array}{l}\text { Aim of study } \\
\text { (environment-related) }\end{array}$} & \multirow[t]{2}{*}{ Functional unit } & \multirow{2}{*}{$\begin{array}{l}\text { System } \\
\text { boundary }\end{array}$} & \multirow{2}{*}{$\begin{array}{l}\text { Impact categories } \\
\text { assessed }^{\text {a }}\end{array}$} & \multirow[t]{2}{*}{ Reference } \\
\hline Species & Farming system & Country & & & & & \\
\hline Atlantic salmon & $\begin{array}{l}\text { Open net-pen } \\
\text { RAS (conceptual) }\end{array}$ & $\begin{array}{l}\text { Norway } \\
\text { USA }\end{array}$ & $\begin{array}{l}\text { Compare the carbon footprint of the } \\
\text { two salmon farming systems, based } \\
\text { on concept-level design }\end{array}$ & $\begin{array}{l}1 \mathrm{~kg} \text { gutted } \\
\text { salmon with head } \\
\text { on, at the retailer } \\
\text { gate }\end{array}$ & $\begin{array}{l}\text { Cradle-to- } \\
\text { market }\end{array}$ & GWP & $\begin{array}{l}\text { Liu et al. } \\
(2016)\end{array}$ \\
\hline Chinook salmon & $\begin{array}{l}\text { A marine confined, } \\
\text { floating tank }\end{array}$ & Canada & $\begin{array}{l}\text { Evaluate the life cycle impacts of the } \\
\text { pilot offshore farming system }\end{array}$ & $\begin{array}{l}1 \text { tonne } \\
\text { live-weight } \\
\text { salmon }\end{array}$ & $\begin{array}{l}\text { Cradle-to- } \\
\text { farm gate }\end{array}$ & $\begin{array}{l}\text { GWP, AP, MEP, CEU, } \\
\text { BRU }\end{array}$ & $\begin{array}{l}\text { McGrath et al. } \\
(2015)\end{array}$ \\
\hline Atlantic salmon & Open net-pen & Norway & $\begin{array}{l}\text { Quantify and compare the carbon } \\
\text { footprint of salmon and other } \\
\text { Norwegian seafood products on the } \\
\text { global seafood market }\end{array}$ & $\begin{array}{l}1 \mathrm{~kg} \text { edible } \\
\text { salmon delivered } \\
\text { to wholesalers in } \\
\text { selected countries }\end{array}$ & $\begin{array}{l}\text { Cradle-to- } \\
\text { market }\end{array}$ & GWP & $\begin{array}{l}\text { Ziegler et al. } \\
(2012)\end{array}$ \\
\hline Atlantic salmon & Open net-pen & Norway & $\begin{array}{l}\text { Compare the carbon footprint, } \\
\text { energy- and area use of farmed } \\
\text { salmon fed with five different diets }\end{array}$ & $\begin{array}{l}1 \mathrm{~kg} \text { edible } \\
\text { salmon }\end{array}$ & $\begin{array}{l}\text { Cradle-to- } \\
\text { farm gate }\end{array}$ & $\begin{array}{l}\text { GWP, CEU, land and sea } \\
\text { area use }\end{array}$ & $\begin{array}{l}\text { Hognes et al. } \\
(2011)\end{array}$ \\
\hline Atlantic salmon & Open net-pen & $\begin{array}{l}\text { Norway, } \\
\text { Canada, } \\
\text { UK, Chile }\end{array}$ & $\begin{array}{l}\text { Analyze the environmental impact of } \\
\text { salmon farmed in the four selected } \\
\text { countries }\end{array}$ & $\begin{array}{l}1 \text { tonne } \\
\text { live-weight } \\
\text { salmon }\end{array}$ & $\begin{array}{l}\text { Cradle-to- } \\
\text { farm gate }\end{array}$ & $\begin{array}{l}\text { CEU, BRU, GHG Em., } \\
\text { Acd. Em., Eut. Em. }\end{array}$ & $\begin{array}{l}\text { Pelletier et al. } \\
(2009)\end{array}$ \\
\hline $\begin{array}{l}\text { Atlantic salmon } \\
\& \text { Arctic Char }\end{array}$ & $\begin{array}{l}\text { Marine net-open, } \\
\text { floating bag; } \\
\text { flow-through; } \\
\text { recirculating }\end{array}$ & Canada & $\begin{array}{l}\text { Assess and compare the life cycle } \\
\text { impacts of the four salmonid culture } \\
\text { systems }\end{array}$ & $\begin{array}{l}1 \text { tonne } \\
\text { live-weight fish }\end{array}$ & $\begin{array}{l}\text { Cradle-to- } \\
\text { farm gate }\end{array}$ & $\begin{array}{l}\text { GWP, EP, AP, ABD, HTP, } \\
\text { MTP, CEU }\end{array}$ & $\begin{array}{l}\text { Ayer and } \\
\text { Tyedmers } \\
(2009)\end{array}$ \\
\hline Atlantic salmon & Open net-pen & Norway & $\begin{array}{l}\text { Analyze the } \mathrm{CO}_{2} \text { emissions both from } \\
\text { salmon farming and transportation to } \\
\text { the wholesaler and consumer }\end{array}$ & $1 \mathrm{~kg}$ salmon fillet & $\begin{array}{l}\text { Cradle-to- } \\
\text { consumer }\end{array}$ & GWP & $\begin{array}{l}\text { Ellingsen et al. } \\
\text { (2009) }\end{array}$ \\
\hline Atlantic salmon & Open net-pen & Norway & $\begin{array}{l}\text { Evaluate the environmental impact of } \\
\text { farmed salmon, compared with } \\
\text { farmed chicken and wild caught cod }\end{array}$ & $\begin{array}{l}0.2 \mathrm{~kg} \text { salmon } \\
\text { fillet sold in } \\
\text { mid-Norway }\end{array}$ & $\begin{array}{l}\text { Cradle-to- } \\
\text { market }\end{array}$ & $\begin{array}{l}\text { GWP, AP/EP, ozone layer, } \\
\text { ecotoxicity, fossil fuels, } \\
\text { carcinogens, RI }\end{array}$ & $\begin{array}{l}\text { Ellingsen and } \\
\text { Aanondsen } \\
(2006)\end{array}$ \\
\hline
\end{tabular}




\section{Section 2: Description of the recirculating Atlantic salmon farming system}

This case study is on Atlantic salmon farmed in an indoor RAS farm in northern China, including three foreground systems: (i) a salmon grow-out RAS farm located in Yantai, Shandong province, northern China, (ii) a hatchery \& smolt rearing facility in Yantai, and (iii) a feed manufacturing plant in Beijing. A brief introduction to the three foreground systems is as follows.

The salmon grow-out RAS plant occupies a total land area of $37500 \mathrm{~m}^{2}$, around 100 meters from the Bohai Sea and 10 meters above sea level. It has been in operation since 2012, with an annual production capacity of 1000 tonnes live-weight salmon. Groundwater was used in this grow-out plant, inlet at a depth of 80-100 meters, with a constant temperature of $14-16^{\circ} \mathrm{C}$ and a salinity of $25-28 \%$. The average grow-out period is around 15 months until harvest at market size of typically 5 kilograms.

The salmon grow-out farm has 78 separated closed-containment systems, each with four rearing tanks and a total rearing volume of $500 \mathrm{~m}^{3}$. The main unit operations of the closed-containment system include: (i) culture tanks with rotary sewage collectors (to remove settleable solids), (ii) automatic fish feeder, (iii) mechanical filtration (to trap solids larger than $30 \mu \mathrm{m}$ in size), (iv) foam fractionator (to remove dissolved organic compounds and fine suspended solids using air bubbles introduced by a venturi jet pump), (v) biological aerated filtration (nitrification and denitrification) \& $\mathrm{CO}_{2}$ stripping (diffusion of $\mathrm{CO}_{2}$ out of water), (vi) UV disinfection (ultraviolet light), (vii) oxygenation (using an oxygen cone to mix liquid oxygen with water to keep the oxygen saturation in the target range of 80-90\%), and (viii) monitoring \& control equipment. Addition of fresh seawater to the system happens at the biofiltration stage. Approximately $90 \%$ recirculated process water goes back to the culture tanks after mechanical \& biological filtration, oxygenation and UV disinfection. At the time of this study, the collected solid fish wastes and sludge from various unit operations of this farm were discharged into the adjunct sea.

The hatchery \& smolt rearing facility is located in Muping District, Yantai, with a distance of 120 $\mathrm{km}$ to the grow-out farmt. Imported salmon eggs come from Aquagen AS in Norway. The salmon eggs are transported by air from Norway to Beijing (around $7850 \mathrm{~km}$ distance), followed by truck from Beijing to Muping $(810 \mathrm{~km})$. Production of smolts takes place in a freshwater RAS and typically has a size of close to 100 gram when transferred to the grow-out farm.

The salmon feed manufacturing plant is located in Miyun District, Beijing Municipality. Raw feed ingredients, mainly derived from fishery, agricultural and livestock products, are milled and reprocessed to fish feed in this plant. The produced salmon feed goes by truck to the smolt hatchery plant $(810 \mathrm{~km})$ and the salmon grow-out plant $(785 \mathrm{~km})$. This study assumed use of the same salmon feed in the hatchery $\&$ smolt rearing facility and the salmon grow-out farm. Detailed feed formulations are listed in Table S2.

Table S2 Feed ingredients of the salmon feed

\begin{tabular}{ll}
\hline Feed ingredients & Feed content (on a dry-weight basis) \\
\hline${\text { Steam dried fish meal }{ }^{\text {a }}}$ & $30 \%$ \\
Fish oil a $^{\text {a }}$ & $15 \%$ \\
Wheat flour & $14 \%$ \\
Soybean meal & $12 \%$ \\
Krill meal & $8 \%$ \\
White fish meal a & $7 \%$ \\
Maize gluten meal & $6 \%$ \\
Chicken meal & $5 \%$ \\
Various minerals, vitamins, colour, etc. & $3 \%$ \\
${ }^{\text {a }}$ The present LCA study assumed that (i) steam dried fishmeal and fish oil came from sand eel, \\
and (ii) white fishmeal came from cod.
\end{tabular}


Section 3: Background data sources and assumptions about the LCI data of feed ingredient production processes

Table S3 Background processes and their data sources (within SimaPro 8.3 software)

\begin{tabular}{llll}
\hline Process & Database & Last updated & Geographic region \\
\hline Electricity production & Ecoinvent v3.3 & 2016 & CN-SD (China-Shandong) \\
Hard coal & Ecoinvent v3.3 & 2016 & CN-HB (China-Hubei) \\
Hydro & Ecoinvent v3.3 & 2016 & CN-SD (China-Shandong) \\
Natural gas & Ecoinvent v3.3 & 2016 & CN-ZJ (China- Zhejiang) \\
Nuclear & Ecoinvent v3.3 & 2016 & CN-SD (China-Shandong) \\
Oil & Ecoinvent v3.3 & 2016 & CN-SD (China-Shandong) \\
Wind & Ecoinvent v3.3 & 2016 & CN-SD (China-Shandong) \\
Photovoltaic & & & \\
Feed ingredients production & LCA Food DK & 2006 & DK (Denmark) \\
Fish meal (sand eel) & LCA Food DK & 2006 & DK (Denmark) \\
Fish oil (sand eel) & LCA Food DK & 2006 & DK (Denmark) \\
Cod, ex harbour & LCA Food DK & 2006 & DK (Denmark) \\
Wheat flour & LCA Food DK & 2006 & DK (Denmark) \\
Shrimp, ex harbour & Ecoinvent v3.3 & 2016 & GLO (Global) \\
Soybean meal & Ecoinvent v3.3 & 2016 & GLO (Global) \\
Chicken meat & Agri-footprint & 2014 & US (United States) \\
Maize gluten meal & & & \\
Infrastructure & Ecoinvent v3.3 & 2016 & GLO (Global) \\
Brick (clay) & Ecoinvent v3.3 & 2016 & RoW (Rest of World) \\
Concrete & Ecoinvent v3.3 & 2016 & GLO (Global) \\
Reinforcing steel & & & \\
Transport & Ecoinvent v3.3 & 2016 & GLO (Global) \\
Freight-lorry & Ecoinvent v3.3 & 2016 & GLO (Global) \\
Freight-aircraft & & & \\
Others & Ecoinvent v3.3 & 2016 & RoW (Rest of World) \\
Liquid oxygen & Ecoinvent v3.3 & 2016 & Global \\
Chlorine dioxide & &
\end{tabular}


Table S4 Notes on Chinese electricity mix and assumptions about feed ingredients production processes

\begin{tabular}{|c|c|c|}
\hline Process & Data source & Notes \& Assumptions \\
\hline $\begin{array}{l}\text { Fish meal (sand eel) } \\
\text { Fish oil (sand eel) }\end{array}$ & Ecoinvent v3.3 & $\begin{array}{l}\text { According to the ecoinvent v3.3 database within SimaPro } 8.3 \text {, the } \\
\text { production of } 1 \mathrm{~kg} \text { fish meal requires } 4.66 \mathrm{~kg} \text { sand eel (ex harbor), } \\
\text { with a byproduct of } 0.21 \mathrm{~kg} \text { fish oil. We applied a mass allocation } \\
\text { between fishmeal }(83 \%) \text { and fish oil }(17 \%) \text { in this study. }\end{array}$ \\
\hline $\begin{array}{l}\text { White fish meal } \\
\text { (cod) }\end{array}$ & $\begin{array}{l}\text { Based on } \\
\text { ecoinvent v3.3 }\end{array}$ & $\begin{array}{l}\text { Based on the above sand eel-based fish meal production process } \\
\text { in the ecoinvent v3.3 database, we assumed that the production of } \\
1 \mathrm{~kg} \text { white fish meal required } 4.66 \mathrm{~kg} \text { cod (ex harbor), with a } \\
\text { byproduct of } 0.21 \mathrm{~kg} \text { fish oil. We applied a mass allocation } \\
\text { between cod-based fishmeal }(83 \%) \text { and fish oil }(17 \%) \text { in this } \\
\text { study. }\end{array}$ \\
\hline \multirow[t]{2}{*}{ Krill meal } & $\begin{array}{l}\text { Parker and } \\
\text { Tyedmers (2012) }\end{array}$ & $\begin{array}{l}\text { According to the authors, the production of } 1 \mathrm{~kg} \text { krill meal } \\
\text { required } 6.94 \mathrm{~kg} \text { wild-caught Antactic krill, with } 0.005 \mathrm{~kg} \text { fish oil } \\
\text { as byproduct. }\end{array}$ \\
\hline & Katevas (2014) & $\begin{array}{l}\text { According to the reference, the price of per kg krill meal and krill } \\
\text { oil was } 2.5 \text { and } 100 \text { USD, respectively. We applied an economic } \\
\text { allocation between krill meal }(83 \%) \text { and krill oil }(17 \%) \text { in this } \\
\text { study. }\end{array}$ \\
\hline Chicken meal & $\begin{array}{l}\text { Based on } \\
\text { ecoinvent v3.3 }\end{array}$ & $\begin{array}{l}\text { According to the process "Chicken for slaughtering, live weight } \\
\{\text { GLO }\} \mid \text { chicken production | Alloc Def, U" in the ecoinvent v3.3 } \\
\text { database within SimaPro } 8.3 \text {, the production of } 1 \mathrm{~kg} \text { fresh chicken } \\
\text { meat required } 1.47 \mathrm{~kg} \text { broilers at farm. Based on the estimated } \\
\text { protein content of chicken meat }(21 \%) \text { and chicken meal }(65 \%) \text {, } \\
\text { we assumed that the production of } 1 \mathrm{~kg} \text { chicken meal required } \\
4.56 \mathrm{~kg} \text { broilers at chicken farm. Owing to data limitation, this } \\
\text { study did not consider heat and/or electricity use in the production } \\
\text { of chicken meal from chicken meat. }\end{array}$ \\
\hline $\begin{array}{l}\text { Chinese electricity } \\
\text { mix }\end{array}$ & $\begin{array}{l}\text { Based on } \\
\text { ecoinvent v3.3 }\end{array}$ & $\begin{array}{l}\text { The Chinese electricity generation processes was updated and } \\
\text { used in this study, according to the actual country electricity mix } \\
\text { in } 2016 \text { (i.e. coal-based } 65.2 \% \text {, hydropower } 19.7 \% \text {, wind } 4 \% \text {, } \\
\text { nuclear } 3.6 \% \text {, natural gas } 3.2 \% \text {, oil } 3.3 \% \text {, and solar } 1 \% \text { ). }\end{array}$ \\
\hline
\end{tabular}




\section{Section 4: Nutrient mass-balance modelling for the production of 1 tonne live-weight salmon at the grow-out farm}

Table S5 Nutrient budget modelling of phosphorous $(\mathrm{P})$ and nitrogen $(\mathrm{N})$ for the production of 1 tonne live-weight salmon at the grow-out farm

\begin{tabular}{|c|c|c|c|c|c|c|c|c|}
\hline & \multirow{2}{*}{$\begin{array}{r}\text { Feed } \\
\text { distributed }^{\mathrm{a}}\end{array}$} & \multirow{2}{*}{$\begin{array}{r}\text { Feed } \\
\text { unconsumed }^{\mathrm{b}}\end{array}$} & \multirow{2}{*}{$\begin{array}{r}\text { Feed } \\
\text { ingested }^{\mathrm{c}}\end{array}$} & \multirow{2}{*}{$\begin{array}{l}\text { Digested } \\
\text { nutrients }\end{array}$} & \multirow{2}{*}{$\begin{array}{l}\text { Faecal } \\
\text { loss }\end{array}$} & \multicolumn{3}{|c|}{ Grow-out effluents ${ }^{\mathrm{f}}$} \\
\hline & & & & & & Nutrient, solid & Nutrient, dissolved & Nutrient, total \\
\hline \multicolumn{9}{|l|}{$\mathrm{eFCR}=1.45$} \\
\hline Total amount (kg) & 1448 & 48 & 1400 & & & & & \\
\hline Solids (kg dry matter) & 1303 & 43 & 1260 & & 304 & & & \\
\hline $\mathrm{N}(\mathrm{kg})$ & 101.8 & 3.4 & 98.4 & 71.5 & 22.1 & 25.4 & 39.7 & 65.1 \\
\hline $\mathrm{P}(\mathrm{kg})$ & 15.1 & 0.5 & 14.6 & 9.4 & 6.9 & 7.4 & 2.8 & 10.2 \\
\hline \multicolumn{9}{|l|}{$\mathrm{eFCR}=1.30$} \\
\hline Total amount (kg) & 1300 & 43 & 1257 & & & & & \\
\hline Solids (kg dry matter) & 1170 & 39 & 1131 & & 273 & & & \\
\hline $\mathrm{N}(\mathrm{kg})$ & 91.4 & 3.0 & 88.4 & 64.2 & 19.8 & 22.9 & 35.6 & 58.5 \\
\hline $\mathrm{P}(\mathrm{kg})$ & 13.5 & 0.4 & 13.1 & 8.4 & 6.2 & 6.6 & 2.6 & 9.2 \\
\hline \multicolumn{9}{|l|}{$\mathrm{eFCR}=1.10$} \\
\hline Total amount (kg) & 1100 & 36 & 1064 & & & & & \\
\hline Solids (kg dry matter) & 990 & 33 & 957 & & 231 & & & \\
\hline $\mathrm{N}(\mathrm{kg})$ & 77.3 & 2.6 & 74.8 & 54.3 & 16.8 & 19.3 & 30.2 & 49.5 \\
\hline $\mathrm{P}(\mathrm{kg})$ & 11.4 & 0.4 & 11.1 & 7.1 & 5.2 & 5.6 & 2.2 & 7.8 \\
\hline
\end{tabular}

a $10 \%$ moisture content of feed; $1 \mathrm{~kg}$ of distributed feed contains $0.07 \mathrm{~kg}$ of $\mathrm{N}$ and $0.01 \mathrm{~kg}$ of $\mathrm{P}$ (data collected from the grow-out farm studied).

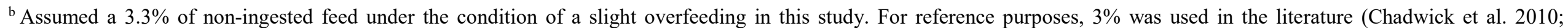
McGrath et al. 2015).

${ }^{\mathrm{c}}$ Feed ingested $=$ Feed distributed - unconsumed feed.

${ }^{\mathrm{d}}$ Calculated mean digestibility of N (73\%) and P (65\%) in salmon feed at this farm, based on the experimental data from Sun (2014).

${ }^{\mathrm{e}}$ Estimated based on an empirical data of the studied grow-out plant, i.e. $1 \mathrm{~kg}$ of feed distributed corresponding to $0.18-0.24 \mathrm{~kg}$ of fecal.

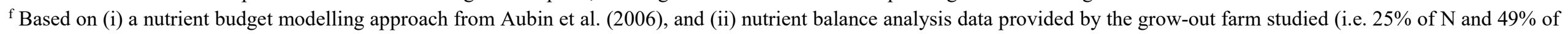

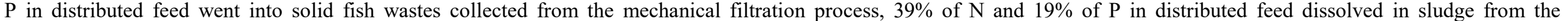
biofiltration process, and the remaining nutrients were assimilated as part of salmon weight-gain). 


\section{Section 5: LCI analysis results of the three foreground processes}

Table S6 Life cycle inventory for producing 1 tonne $(\mathrm{t})$ of live-weight salmon, $1 \mathrm{t}$ of smolt and $1 \mathrm{t}$ of feed product, respectively ${ }^{\mathrm{a}}$

\begin{tabular}{|c|c|c|c|}
\hline & Salmon grow-out & Smolt production & $\begin{array}{l}\text { Feed } \\
\text { manufacuring }\end{array}$ \\
\hline \multicolumn{4}{|l|}{ Outputs - product (t) } \\
\hline Atlantic salmon, live-weight & 1 & - & - \\
\hline Salmon smolts & - & 1 & - \\
\hline Salmon feed & - & - & 1 \\
\hline \multicolumn{4}{|l|}{ Inputs - operational $(/ \mathrm{t})^{\mathrm{b}}$} \\
\hline Smolt (kg) & 24.1 & - & - \\
\hline Feed $(\mathrm{kg})$ & 1448 & 1010 & - \\
\hline Feed ingredients $(\mathrm{t})$ & - & - & $1.01^{\mathrm{c}}$ \\
\hline Electricity (kWh) & 7509 & 1944 & 300 \\
\hline Water $\left(\mathrm{m}^{3}\right)$ & 1862 (seawater) & 2000 (freshwater) & $\mathrm{n} / \mathrm{a}$ \\
\hline Liquid oxygen $(\mathrm{kg})$ & 953 & 714 & - \\
\hline Chlorine dioxide $(\mathrm{kg})^{\mathrm{d}}$ & 1.45 & - & - \\
\hline $\begin{array}{l}\text { Salmon eggs transport (tkm) / } \\
\text { distance }(\mathrm{km})^{\mathrm{e}}\end{array}$ & - & $\begin{array}{l}75 / 7850 \text { (air) } \\
7.2 / 750 \text { (truck) }\end{array}$ & - \\
\hline Smolt transport $(\mathrm{tkm}) /$ distance $(\mathrm{km})$ & $2.9 / 120$ (truck) & - & - \\
\hline Feeds transport $(\mathrm{tkm}) /$ distance $(\mathrm{km})$ & 1137 / 785 (truck) & 818 / 810 (truck) & - \\
\hline Feed ingredients transport & - & - & $\mathrm{n} / \mathrm{a}$ \\
\hline \multicolumn{4}{|l|}{ Inputs - infrastructure $(\mathrm{kg} / \mathrm{t})^{\mathrm{f}}$} \\
\hline Concrete & 6201 & $\mathrm{n} / \mathrm{a}$ & $\mathrm{n} / \mathrm{a}$ \\
\hline Reinforcing steel & 144 & $\mathrm{n} / \mathrm{a}$ & $\mathrm{n} / \mathrm{a}$ \\
\hline Brick & 3448 & $\mathrm{n} / \mathrm{a}$ & $\mathrm{n} / \mathrm{a}$ \\
\hline \multicolumn{4}{|l|}{ Outputs - emissions to water $(\mathrm{kg} / \mathrm{t})$} \\
\hline Phosphorous, dissolved & 2.9 & $\mathrm{n} / \mathrm{a}$ & $\mathrm{n} / \mathrm{a}$ \\
\hline Phosphorous, solid & 7.4 & $\mathrm{n} / \mathrm{a}$ & $\mathrm{n} / \mathrm{a}$ \\
\hline Nitrogen, dissolved & 39.7 & $\mathrm{n} / \mathrm{a}$ & $\mathrm{n} / \mathrm{a}$ \\
\hline Nitrogen, solid & 25.4 & $\mathrm{n} / \mathrm{a}$ & $\mathrm{n} / \mathrm{a}$ \\
\hline
\end{tabular}

a " $\mathrm{n} / \mathrm{a}$ " is shown where data were missing.

${ }^{\mathrm{b}}$ No chemicals were used during the grow-out period studied.

${ }^{\mathrm{c}}$ Assuming 1\% processing losses in the feed manufacturing plant.

${ }^{\mathrm{d}}$ Added into the rearing tanks during hot seasons for disinfection, disease resistance and inhibiting algae breeding.

e $\mathrm{tkm}=$ tonne $\times$ kilometers.

${ }^{\mathrm{f}}$ The culture tank material is concrete. This study used the density of 2.4 tonne $/ \mathrm{m}^{3}$ for concrete and 2 tonne $/ \mathrm{m}^{3}$ for brick as well as 15-year lifespan of the grow-out infrastructure. 


\section{Section 6: On-site electricity use for the production of 1 tonne live-weight salmon}

Table S7 Total and breakdown of on-site electricity use for the production of 1 tonne harvest-ready live-weight salmon

\begin{tabular}{lrr}
\hline \multirow{2}{*}{ Foreground system } & \multicolumn{2}{c}{ On-site electricity use } \\
\cline { 2 - 3 } & Value $(\mathrm{kWh})$ & Percent \\
\hline Salmon grow-out farm & & \\
Water circulation pump & 3079 & $36.6 \%$ \\
Make-up water supply pump & 1862 & $22.1 \%$ \\
UV lamp & 1386 & $16.5 \%$ \\
Biofilter blowers & 770 & $9.1 \%$ \\
Protein skimmer (jet pump) & 154 & $1.8 \%$ \\
Mechanical filter & 77 & $0.9 \%$ \\
Oxygen cone (jet pump) & 77 & $0.9 \%$ \\
Illumination lamps & 58 & $0.7 \%$ \\
Automatic fish feeder & 47 & $0.6 \%$ \\
Salmon grow-out in all & $\mathbf{7 5 0 9}$ & $\mathbf{8 9 . 2 \%}$ \\
Hatchery \& smolt rearing facility & & \\
Water circulation pump & 243 & $2.9 \%$ \\
Refrigerating machines & 139 & $1.7 \%$ \\
Water supply pump & 42 & $0.5 \%$ \\
Air pump & 36 & $0.4 \%$ \\
Artificial light & 9 & $0.1 \%$ \\
Smolt production in all & $\mathbf{4 6 9}$ & $\mathbf{5 . 6 \%}$ \\
Feed manufacturing plant & & \\
Feed milling & 442 & $5.2 \%$ \\
Feed manufacturing in all & $\mathbf{4 4 2}$ & $\mathbf{5 . 2 \%}$ \\
In all & $\mathbf{8 4 2 0}$ & $\mathbf{1 0 0 \%}$ \\
\hline
\end{tabular}


Section 7: Results of LCIA per tonne live-weight salmon, per tonne feed product, and per tonne specific feed ingredients, respectively

Table S8 Life cycle impacts per tonne live-weight Atlantic salmon harvested at the grow-out farm, cradle-to-farm gate (ReCiPe midpoint/hierarchist v1.13 and CED v1.09)

\begin{tabular}{|c|c|c|c|c|c|c|c|c|c|}
\hline & $\begin{array}{r}\mathrm{CC} \\
(\mathrm{kg} \mathrm{CO} 2 \\
\text { eq) }\end{array}$ & $\begin{array}{r}\mathrm{TA} \\
\left(\mathrm{kg} \mathrm{SO}_{2}\right. \\
\mathrm{eq})\end{array}$ & $\begin{array}{r}\text { FEU } \\
\text { (kg P } \\
\text { eq) }\end{array}$ & $\begin{array}{r}\text { MEU } \\
(\mathrm{kg} \mathrm{N} \\
\text { eq) }\end{array}$ & $\begin{array}{r}\mathrm{HT} \\
(\mathrm{kg} 1.4- \\
\mathrm{DB} \text { eq) }\end{array}$ & $\begin{array}{r}\text { TET } \\
\text { (kg 1.4- } \\
\text { DB eq) }\end{array}$ & $\begin{array}{r}\text { FET } \\
\text { (kg 1.4- } \\
\text { DB eq) }\end{array}$ & $\begin{array}{r}\text { MET } \\
\text { (kg 1.4- } \\
\text { DB eq) }\end{array}$ & $\begin{array}{l}\text { CED } \\
\text { (MJ) }\end{array}$ \\
\hline Total & 16747 & 106 & 2.4 & 108 & 2245 & 15 & 91 & 82 & 203257 \\
\hline $\begin{array}{l}\text { Feed } \\
\text { production }\end{array}$ & 5115 & 50 & 0.4 & 13 & 320 & 14 & 12 & 8.5 & 75354 \\
\hline Feed transport & 246 & 1 & 0.02 & 0.1 & 67 & 0.1 & 0.9 & 1 & 4000 \\
\hline $\begin{array}{l}\text { Smolt } \\
\text { production }\end{array}$ & 592 & 3.4 & 0.1 & 0.3 & 68 & 0.2 & 3 & 3 & 6677 \\
\hline $\begin{array}{l}\text { Smolt } \\
\text { transport }\end{array}$ & 0.6 & 0.003 & 0.0001 & 0.0002 & 0.2 & 0.0002 & 0.002 & 0.004 & 10 \\
\hline Liquid oxygen & 1106 & 5 & 0.5 & 0.2 & 364 & 0.1 & 12 & 11 & 15378 \\
\hline $\begin{array}{l}\text { Chlorine } \\
\text { dioxide }\end{array}$ & 12 & 0.1 & 0.01 & 0.01 & 6 & 0.001 & 0.2 & 0.2 & 191 \\
\hline $\begin{array}{l}\text { Grow-out } \\
\text { electricity }\end{array}$ & 7692 & 39 & 1 & 1 & 882 & 0.1 & 47 & 43 & 80656 \\
\hline $\begin{array}{l}\text { Grow-out } \\
\text { effluents }\end{array}$ & 0 & 0 & 0 & 93 & 0 & 0 & 0 & 0 & 0 \\
\hline $\begin{array}{l}\text { Grow-out } \\
\text { infrastructure }\end{array}$ & 1983 & 7 & 0.4 & 0.3 & 537 & 0.2 & 15 & 15 & 23041 \\
\hline
\end{tabular}

Table S9 Relative contribution of the life cycle impacts per tonne live-weight Atlantic salmon harvested at the grow-out farm, cradle-to-farm gate (ReCiPe midpoint/hierarchist v1.13 and CED v1.09)

\begin{tabular}{lccccccccc}
\hline & $\begin{array}{c}\text { CC } \\
(\%)\end{array}$ & $\begin{array}{c}\text { TA } \\
(\%)\end{array}$ & $\begin{array}{c}\text { FEU } \\
(\%)\end{array}$ & $\begin{array}{c}\text { MEU } \\
(\%)\end{array}$ & $\begin{array}{c}\text { HT } \\
(\%)\end{array}$ & $\begin{array}{c}\text { TET } \\
(\%)\end{array}$ & $\begin{array}{c}\text { FET } \\
(\%)\end{array}$ & $\begin{array}{c}\text { MET } \\
(\%)\end{array}$ & $\begin{array}{c}\text { CED } \\
(\%)\end{array}$ \\
\hline Total & 100 & 100 & 100 & 100 & 100 & 100 & 100 & 100 & 100 \\
Feed production & 30.5 & 47.5 & 15.0 & 11.8 & 14.3 & 95.0 & 13.2 & 10.3 & 37.1 \\
Feed transport & 1.5 & 1.2 & 0.9 & 0.1 & 3.0 & 0.6 & 1.0 & 1.7 & 2.0 \\
$\begin{array}{l}\text { Smolt } \\
\text { production }\end{array}$ & 3.5 & 3.2 & 3.3 & 0.3 & 3.0 & 1.7 & 3.7 & 3.7 & 3.3 \\
$\begin{array}{l}\text { Smolt } \\
\text { transport }\end{array}$ & 0.004 & 0.003 & 0.002 & 0.0002 & 0.01 & 0.002 & 0.003 & 0.004 & 0.01 \\
$\begin{array}{l}\text { Liquid oxygen } \\
\begin{array}{l}\text { Chlorine } \\
\text { dioxide }\end{array}\end{array}$ & 6.6 & 4.9 & 22.2 & 0.2 & 16.2 & 0.4 & 13.5 & 13.6 & 7.6 \\
$\begin{array}{l}\text { Grow-out } \\
\text { electricity }\end{array}$ & 0.1 & 0.1 & 0.3 & 0.01 & 0.3 & 0.01 & 0.2 & 0.2 & 0.1 \\
$\begin{array}{l}\text { Grow-out } \\
\text { effluents }\end{array}$ & 0 & 0 & 0 & 86.5 & 0 & 0 & 0 & 0 & 0 \\
$\begin{array}{l}\text { Grow-out } \\
\text { infrastructure }\end{array}$ & 11.8 & 6.3 & 16.7 & 0.3 & 23.9 & 1.4 & 16.7 & 18.1 & 10.3 \\
\hline
\end{tabular}


Table S10 Life cycle impacts per tonne salmon feed product, cradle-to-gate (ReCiPe midpoint/hierarchist v1.13 and CED v1.09)

\begin{tabular}{|c|c|c|c|c|c|c|c|c|c|}
\hline & $\begin{array}{r}\mathrm{CC} \\
\left(\mathrm{kg} \mathrm{CO}_{2}\right. \\
\text { eq) }\end{array}$ & $\begin{array}{r}\mathrm{TA} \\
\left(\mathrm{kg} \mathrm{SO}_{2}\right. \\
\text { eq) }\end{array}$ & $\begin{array}{r}\text { FEU } \\
\text { (kg P } \\
\text { eq) }\end{array}$ & $\begin{array}{r}\text { MEU } \\
(\mathrm{kg} \mathrm{N} \\
\text { eq) }\end{array}$ & $\begin{array}{r}\mathrm{HT} \\
\text { (kg 1.4- } \\
\text { DB eq) }\end{array}$ & $\begin{array}{r}\text { TET } \\
\text { (kg 1.4- } \\
\text { DB eq) }\end{array}$ & $\begin{array}{r}\text { FET } \\
\text { (kg 1.4- } \\
\text { DB eq) }\end{array}$ & $\begin{array}{r}\text { MET } \\
\text { (kg 1.4- } \\
\text { DB eq) }\end{array}$ & $\begin{array}{l}\text { CED } \\
\text { (MJ) }\end{array}$ \\
\hline Total & 3532 & 35 & 0.3 & 8.8 & 221 & 10 & 8.3 & 5.8 & 52030 \\
\hline $\begin{array}{l}\text { Fish meal } \\
(\operatorname{cod})\end{array}$ & 364 & 3.3 & 0.002 & 0.2 & 11 & 0.01 & 0.2 & 0.2 & 4851 \\
\hline $\begin{array}{l}\text { Fishmeal } \\
\text { (sand eel) }\end{array}$ & 369 & 2.5 & 0.01 & 0.3 & 16 & 0.01 & 0.4 & 0.4 & 502 \\
\hline $\begin{array}{l}\text { Fish oil } \\
\text { (sand eel) }\end{array}$ & 185 & 1.2 & 0.004 & 0.1 & 8.2 & 0.003 & 0.2 & 0.2 & 2517 \\
\hline Krill meal & 1320 & 14 & 0.002 & 0.9 & 34 & 0.02 & 0.4 & 0.4 & 17485 \\
\hline Wheat flour & 139 & 1.1 & 0.002 & 2.2 & 0.8 & 0.001 & 0.01 & 0.01 & 690 \\
\hline Soybean meal & 302 & 0.4 & 0.03 & 0.7 & 15 & 4.6 & 1.1 & 0.4 & 4639 \\
\hline $\begin{array}{l}\text { Maize gluten } \\
\text { meal }\end{array}$ & 6 & 0.04 & 0.001 & 0.001 & 1.0 & 0.2 & 0.3 & 0.04 & 1018 \\
\hline Chicken meal & 539 & 11 & 0.2 & 4.3 & 99 & 4.8 & 3.9 & 2.5 & 12584 \\
\hline $\begin{array}{l}\text { Electricity } \\
\text { (feed milling) }\end{array}$ & 307 & 1.6 & 0.04 & 0.04 & 35 & 0.01 & 1.9 & 1.7 & 3222 \\
\hline
\end{tabular}

Table S11 Life cycle impacts per tonne specific feed ingredient, cradle-to-gate (ReCiPe midpoint/hierarchist v1.13 and CED v1.09) a,b

\begin{tabular}{|c|c|c|c|c|c|c|c|c|c|}
\hline & $\begin{array}{r}\mathrm{CC} \\
\left(\mathrm{kg} \mathrm{CO}_{2}\right. \\
\mathrm{eq})\end{array}$ & $\begin{array}{r}\mathrm{TA} \\
\left(\mathrm{kg} \mathrm{SO} \mathrm{SO}_{2}\right. \\
\mathrm{eq})\end{array}$ & $\begin{array}{r}\text { FEU } \\
(\mathrm{kg} \mathrm{P} \\
\mathrm{eq})\end{array}$ & $\begin{array}{r}\text { MEU } \\
(\mathrm{kg} \mathrm{N} \\
\text { eq) }\end{array}$ & $\begin{array}{r}\mathrm{HT} \\
\text { (kg 1.4- } \\
\text { DB eq) }\end{array}$ & $\begin{array}{r}\text { TET } \\
\text { (kg 1.4- } \\
\text { DB eq) }\end{array}$ & $\begin{array}{r}\text { FET } \\
\text { (kg 1.4- } \\
\text { DB eq) }\end{array}$ & $\begin{array}{r}\text { MET } \\
\text { (kg 1.4- } \\
\text { DB eq) }\end{array}$ & $\begin{array}{l}\text { CED } \\
\text { (MJ) }\end{array}$ \\
\hline $\begin{array}{l}\text { Fish meal } \\
\text { (cod) }\end{array}$ & 5129 & 47 & 0.03 & 3.5 & 150 & 0.1 & 2.3 & 2.4 & 68320 \\
\hline $\begin{array}{l}\text { Fishmeal } \\
\text { (sand eel) }\end{array}$ & 1218 & 8.1 & 0.03 & 0.9 & 54 & 0.02 & 1.3 & 1.3 & 16581 \\
\hline $\begin{array}{l}\text { Fish oil } \\
\text { (sand eel) }\end{array}$ & 1217 & 8.1 & 0.03 & 0.9 & 54 & 0.02 & 1.3 & 1.3 & 16559 \\
\hline Krill meal & 16302 & 173 & 0.02 & 11 & 425 & 0.2 & 4.4 & 4.9 & 215866 \\
\hline Chicken meal & 10574 & 206 & 3.3 & 85 & 1945 & 93 & 77 & 49 & 246736 \\
\hline Soybean meal & 2492 & 3.4 & 0.2 & 5.6 & 127 & 38 & 9 & 3.4 & 38340 \\
\hline Wheat flour & 986 & 7.6 & 0.01 & 15 & 5.4 & 0.004 & 0.03 & 0.1 & 4892 \\
\hline $\begin{array}{l}\text { Maize gluten } \\
\text { meal }\end{array}$ & 93 & 0.6 & 0.02 & 0.02 & 16 & 3.2 & 4.3 & 0.7 & 16689 \\
\hline
\end{tabular}

${ }^{a}$ For more information on the data and assumptions for feed ingredient production processes, see Tables S3 and S4.

b The original electricity mix for processing raw product of fish/shrimp at harbor to produce the corresponding feed ingredients (fish meal/oil and krill meal) in the ecoinvent v3.3 database was replaced with the updated Chinese electricity mix (2016). 


\section{Section 8: Sensitivity, scenario and uncertainty analyses}

\section{Sensitivity and scenario analyses}

Sensitivity and scenario analyses were conducted to investigate how the life cycle impacts per tonne live-weight salmon change with the following LCI parameters and scenarios: (i) grow-out stocking density, (ii) eFCR, (iii) life expectancy of the grow-out infrastructure, (iv) feed ingredients (taking substitution of krill meal and chicken meal with soybean meal as an example), and (v) electricity generation sources (shifting from coal-dominated to less fossil fuel energy).

Those LCI parameters and scenarios were selected based on the results of life cycle contribution analysis of the cradle-to-gate salmon RAS farming system (Figure 2) and feed production processes (Figure 3), which were identified as important contributors of the life cycle impacts per tonne live-weight salmon harvested at the grow-out farm studied. Results of the sensitivity and scenario analyses were listed in Table 1 of the main part of this paper. Below was a summary of the analysis results and background information on the alternative parameters used in the analyses.

Firstly, the influence of grow-out stocking density on the life cycle impacts were modelled in relation to (i) baseline: $24.2 \mathrm{~kg} / \mathrm{m}^{3}$, (ii) scenario 1 (S1): $45 \mathrm{~kg} / \mathrm{m}^{3}$ (the design stocking density of this grow-out farm), and (iii) scenario 2 (S2): $60 \mathrm{~kg} / \mathrm{m}^{3}$ (representing high-density operation but requiring higher operational management skills). Based on the technical design data of this grow-out farm, the following assumptions were made in the sensitivity analysis: (i) the total farm-level electricity use per generation in S1 was same to that associated with the baseline stocking density, while in S2 it was estimated to be 1.4 times of the baseline, and (ii) the total farm-level liquid oxygen consumption in S1 and S2 was 1.6 and 2.2 times, respectively, of the baseline. Results of the analysis showed that, compared to the baseline, S1 and S2 led to a similar change in each specific impact category, reducing by up to $1.3 \%$ of MEU and TET and $20-35 \%$ in the other seven categories.

Secondly, the effect of eFCR was modelled in two alternative eFCR at 1.1 and 1.3. The selection of two alternative eFCR (1.3 and 1.1) was based on the following information in the literature: (i) Pelletier et al. (2009) reported that the eFCR of farmed salmon was 1.1 in Norway, 1.33 in the UK, 1.31 in Canada, and 1.49 in Chile, and (ii) Liu et al. (2016) reported an eFCR of 1.09 in a conceptual Atlantic salmon RAS plant, based on conceptual-level design. Compared to the baseline eFCR at 1.45 , the results of sensitivity analysis showed that the eFCR at 1.3 and 1.1 resulted in a reduction by around $10 \%$ and $23 \%$, respectively, in the MEU and TET impact categories. For the other seven impact categories, the two alternative eFCR led to a reduction by $1-11 \%$ of the potential environmental impacts.

Thirdly, the 10-year (S1) and 20-year (S2) life expectancy of grow-out infrastructure led to increase by up to $11 \%$ and decrease by up to $6 \%$ of all impact categories, respectively, compared to the baseline (15-year).

Fourthly, the impacts of feed ingredients were analyzed in two scenarios: S1 - substitution of krill meal $(8 \%)$ with soybean meal $(8 \%)$, and S2 - substitution of chicken meal $(5 \%)$ with soybean meal (5\%). Compared to the baseline, the scenario results showed that the life cycle impacts in S1 increased by $31 \%$ in TET and decreased by $9-19 \%$ in CC, TA and CED, while the life cycle impacts in S2 reduced by $4-28 \%$ in all categories (highest reduction in TET and lowest in CC).

Finally, two scenarios of electricity generation sources were compared with the baseline: (i) baseline, Chinese electricity mix in 2016 (coal $65.2 \%$, hydropower $19.7 \%$, wind $4 \%$, nuclear $3.6 \%$, others $7.5 \%$ ); (ii) S1: replacing $20 \%$ electricity generated from coal with wind (coal $45.2 \%$, hydropower $19.7 \%$, wind $24 \%$, nuclear $3.6 \%$, others $7.5 \%$ ); (iii) S2: replacing $20 \%$ electricity generated from coal with nuclear power (coal $45.2 \%$, hydropower $19.7 \%$, wind $4 \%$, nuclear $23.6 \%$, others $7.5 \%$ ). Since the current Chinese electricity mix is coal-dominated (65\%), China has planned to increase the share of non-fossil sources to $20 \%$ in national primary energy use by 2030 . A key focus of the national energy policy initiatives is on expanding wind-generated electricity (Davidson et al. 2016). The results of S1 and S2 showed a similar trend in six impact categories, namely a reduction by $8-15 \%$ in CC, TA, FE and HT 
while up to $0.5 \%$ in MEU and TET. Compared to the baseline, the respective MET and FET impact decreased by around $14 \%$ in S2, but they increased by $7.8 \%$ and $9 \%$ in S1 (mainly owing to copper leaching into water from treatment of scrap copper after use in electric power transmissions). For CED, the comparison results showed 7\% decrease in S1 and 0.9\% increase in S2.

It is worth noting that there are non-linear relationships between fish growth rate and stocking density \& eFCR during the grow-out period in practice. In this case study, there may be no significant differences in fish growth rate during the whole grow-out period between the stocking density of 24.2 $\mathrm{kg} / \mathrm{m}^{3}$ and $45 \mathrm{~kg} / \mathrm{m}^{3}$, since this grow-out plant was designed for an optimum stocking density of 45 $\mathrm{kg} / \mathrm{m}^{3}$. When increasing the stocking density from $45 \mathrm{~kg} / \mathrm{m}^{3}$ to $60 \mathrm{~kg} / \mathrm{m}^{3}$, there is currently no operational data at this grow-out plant and there may be some kind of marginal decrease in fish growth rate. In a 10-week stress-oriented experiment conducted at the same salmon grow-out farm, Liu et al. (2015) reported that the growth rate of 14-month-old post-smolts decreased by $1.6 \%$ at medium-density (15.1-31.1 kg/m $\mathrm{m}^{3}$, initial-final density) and by $3.8 \%$ at high-density $\left(30.2-61.3 \mathrm{~kg} / \mathrm{m}^{3}\right)$, compared to low-density $\left(7.6-15.7 \mathrm{~kg} / \mathrm{m}^{3}\right)$. According to Chadwick et al. (2010), rearing density of up to $80 \mathrm{~kg} / \mathrm{m}^{3}$ does not limit growth rate of Atlantic salmon in closed-containment systems where water quality is maintained at acceptable levels. For the sake of simplification, this study applied the eFCR of 1.1 and 1.3 directly in the sensitivity analysis, and the sensitivity analysis of feed ingredient substitution did not consider the differences in the protein and lipid content of alternative feed ingredients. Therefore, there would be uncertainties in the results of sensitivity and scenario analyses. In future studies, it is needed to develop models for a systematic analysis of possible relationships between fish growth rate, substitution of feed ingredients, and operational performance (e.g. stocking density, eFCR, electricity use, oxygen requirements) during the whole grow-out period.

\section{Uncertainty analysis}

In order to estimate the effect of uncertainty sources on the respective life cycle impacts per tonne salmon and feed product, Monte Carlo uncertainty analyses were conducted using ReCiPe Midpoint $(\mathrm{H})$ V1.13 / World Recipe H in SimaPro v8.3. Table S12 presented the uncertainty analysis results of this study.

Table S12 Monte Carlo analysis for the cradle-to-gate life cycle impacts of one tonne of live-weight salmon at the grow-out farm and one tonne of salmon feed at the feed manufacturing plant, respectively

\begin{tabular}{|c|c|c|c|c|c|c|c|c|}
\hline \multirow{2}{*}{ Impact category } & \multicolumn{4}{|c|}{1 tonne live-weight salmon } & \multicolumn{4}{|c|}{1 tonne salmon feed } \\
\hline & Mean & Median & SD & $\mathrm{CV}(\%)$ & Mean & Median & SD & CV $(\%)$ \\
\hline $\mathrm{CC}\left(\mathrm{kg} \mathrm{CO}_{2}\right.$ eq $)$ & 16763 & 16591 & 1496 & 8.9 & 3532 & 3523 & 106 & 3 \\
\hline $\mathrm{TA}\left(\mathrm{kg} \mathrm{SO}_{2} \mathrm{eq}\right)$ & 106 & 104 & 12 & 11 & 35 & 35 & 1.1 & 3 \\
\hline FEU (kg P eq) & 2.5 & 2.2 & 1.2 & 50 & 0.3 & 0.3 & 0.1 & 35 \\
\hline MEU (kg N eq) & 108 & 108 & 1.0 & 0.9 & 9 & 9 & 0.6 & 7 \\
\hline HT (kg 1.4- DB eq) & 2258 & 1847 & 2109 & 93 & 218 & 194 & 91 & 42 \\
\hline TET (kg 1.4- DB eq) & 15 & 14 & 2.4 & 16 & 10 & 9 & 2 & 17 \\
\hline FET (kg 1.4- DB eq) & 91 & 87 & 23 & 25 & 8 & 8 & 1.4 & 17 \\
\hline MET (kg 1.4- DB eq) & 82 & 79 & 21 & 25 & 6 & 6 & 1.2 & 21 \\
\hline
\end{tabular}

Note: SD, standard deviation; CV, coefficient of variation; confidence interval $95 \%$. 


\section{Section 9: Comparison of the grow-out LCI data between this study and the literature}

Table S13 Comparison of the grow-out LCI data for the production of one tonne live-weight salmonid fish between this study and the literature

\begin{tabular}{|c|c|c|c|c|c|c|c|c|c|}
\hline \multirow[t]{2}{*}{ Reference } & \multirow[t]{2}{*}{ Species } & \multirow[t]{2}{*}{ Farming system } & \multirow{2}{*}{$\begin{array}{l}\text { Production losses } \\
\text { (mortality/others) } \\
(\%)\end{array}$} & \multirow{2}{*}{$\begin{array}{l}\text { Stocking } \\
\text { density } \\
\left(\mathrm{kg} / \mathrm{m}^{3}\right)\end{array}$} & \multirow{2}{*}{$\begin{array}{l}\text { Liquid } \\
\text { oxygen } \\
(\mathrm{kg} / \mathrm{t})\end{array}$} & \multirow{2}{*}{$\begin{array}{l}\text { Electricity } \\
\text { use, on-site } \\
(\mathrm{kWh} / \mathrm{t})\end{array}$} & \multirow{2}{*}{$\begin{array}{l}\text { Economic } \\
\text { FCR } \\
(\mathrm{t} / \mathrm{t})\end{array}$} & \multicolumn{2}{|c|}{ On-site nutrient emissions $(\mathrm{kg} / \mathrm{t})$} \\
\hline & & & & & & & & $\begin{array}{l}\text { Total N } \\
\text { (solid/dissolved) }\end{array}$ & $\begin{array}{l}\text { Total P } \\
\text { (solid/dissolved) }\end{array}$ \\
\hline \multirow[t]{5}{*}{ This study } & \multirow{5}{*}{$\begin{array}{l}\text { Atlantic } \\
\text { salmon }\end{array}$} & \multirow{5}{*}{$\begin{array}{l}\text { Land-based RAS, } \\
\text { China }\end{array}$} & \multirow[t]{5}{*}{$17(13 / 4)$} & 24.2 & 953 & 7509 & 1.45 & $65.1(25.4 / 39.7)$ & $10.2(7.4 / 2.8)$ \\
\hline & & & & & & & $1.30(\mathrm{~S} 1)$ & $58.5(22.9 / 35.6)$ & $9.2(6.6 / 2.6)$ \\
\hline & & & & & & & $1.10(\mathrm{~S} 2)$ & $49.5(19.3 / 30.2)$ & $7.8(5.6 / 2.2)$ \\
\hline & & & & $45(\mathrm{~S} 1)$ & $819^{a}$ & 4033 & 1.45 & 30.3 & 5.7 \\
\hline & & & & $60(\mathrm{~S} 2)$ & $844^{\mathrm{a}}$ & 4234 & 1.45 & 30.3 & 5.7 \\
\hline \multirow[t]{2}{*}{$\begin{array}{l}\text { Liu et al. } \\
(2016)^{b}\end{array}$} & \multirow[t]{2}{*}{$\begin{array}{l}\text { Atlantic } \\
\text { salmon }\end{array}$} & $\begin{array}{l}\text { Land-based RAS } \\
\text { (conceptual), USA }\end{array}$ & 16 & 80 & 656 & 5460 & $1.09^{b}$ & $\mathrm{n} / \mathrm{a}$ & $\mathrm{n} / \mathrm{a}$ \\
\hline & & $\begin{array}{l}\text { Open net-pen, } \\
\text { Norway }\end{array}$ & 16 & 25 & - & - & 1.27 & $\mathrm{n} / \mathrm{a}$ & $\mathrm{n} / \mathrm{a}$ \\
\hline $\begin{array}{l}\text { McGrath et } \\
\text { al. (2015) }\end{array}$ & $\begin{array}{l}\text { Chinook } \\
\text { salmon }\end{array}$ & $\begin{array}{l}\text { Marine floating } \\
\text { confined tank, } \\
\text { Canada }\end{array}$ & $22.7(17.8 / 4.9)^{c}$ & 26.6 & - & 7272 & 1.46 & $60.2(9.8 / 50.4)$ & $11.9(8.2 / 3.7)$ \\
\hline \multirow[t]{2}{*}{$\begin{array}{l}\text { Ayer and } \\
\text { Tyedmers } \\
(2009)\end{array}$} & $\begin{array}{l}\text { Atlantic } \\
\text { salmon }\end{array}$ & $\begin{array}{l}\text { Land-based, } \\
\text { flow-through, } \\
\text { Canada }\end{array}$ & In mass $^{d}$ & 38 & 1445 & 13400 & 1.17 & $26.0^{\mathrm{e}}$ & $4.1^{\mathrm{e}}$ \\
\hline & $\begin{array}{l}\text { Arctic } \\
\text { char }\end{array}$ & $\begin{array}{l}\text { Land-based, } \\
\text { recirculating, } \\
\text { Canada }\end{array}$ & In mass ${ }^{f}$ & 73 & - & 22600 & 1.45 & $0^{\mathrm{g}}$ & $0^{g}$ \\
\hline
\end{tabular}

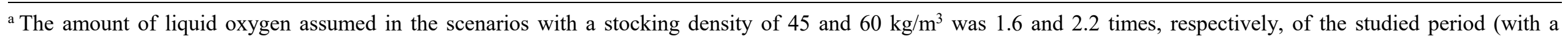
stocking density of $24.2 \mathrm{~kg} / \mathrm{m}^{3}$ ). It assumed a same nutrient emission level per tonne salmon (at eFCR of 1.45) for the three densities.

${ }^{\mathrm{b}}$ The FU was $1 \mathrm{~kg}$ gutted salmon with head on (at the retailer gate) and the eFCR was estimated for a concept-level closed containment system (Liu et al. 2016).

${ }^{\mathrm{c}}$ The generation period with a number of stocked smolts (56108), salmon harvested (43366), mortalities (9989) and escapes (2753) (McGrath et al. 2015).

${ }^{\mathrm{d}}$ The weight of stocked smolts $(14.6 \mathrm{~kg})$ and mortalities $(84.4 \mathrm{~kg})$ per tonne live-weight harvested fish (Ayer and Tyedmers 2009$)$.

${ }^{\mathrm{e}}$ Wastewater leaving the rearing tanks was untreated and piped back into the channel; no specification on the forms of nutrients (Ayer and Tyedmers 2009).

${ }^{\mathrm{f}}$ The weight of stocked smolts $(238 \mathrm{~kg})$ and mortalities $(301 \mathrm{~kg})$ for the production of 1 tonne live-weight fish (Ayer and Tyedmers 2009$)$.

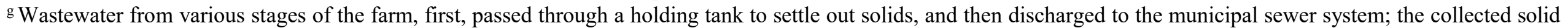
fish wastes contained $6.8 \mathrm{~kg}$ of sequestered $\mathrm{N}$ and $3.2 \mathrm{~kg}$ of sequestered P per tonne of live-weight fish (Ayer and Tyedmers 2009). 


\section{Section 10: Limitations of the present study}

A limitation of the present study relates to the following two issues: (i) data and data quality of feed ingredient production (background processes), and (ii) those excluded foreground processes and parameters.

On one hand, this study used generic feed ingredient production data (from databases in SimaPro v8.3), together with a number of literature-based assumptions for missing processes (Table S4, supporting information). Regarding the feed ingredients for production of salmon feed in this study, part of them, including fish meal and oil, were produced in China. However, there is not yet published LCI data on Chinese fisheries and fishmeal production processes. Under such circumstances, it is hard to conclude whether the LCIA results of feed production in this study was overestimated or underestimated, though transport of feed ingredients to the Chinese feed manufacturing plant was excluded from the system studied. On the other hand, the LCIA results of infrastructure (part of foreground systems) may be underestimated, since only building materials of the grow-out farm were included in this study.

To better support LCA as an environmental decision support tool for aquaculture, further LCI-oriented research is needed, especially on cradle-to-gate feed ingredient production processes and more detailed analysis of other relevant processes (e.g. building materials, transportation, on-site wastes/emissions, disinfectants, vitamins, and antibiotics), which may further unveil neglected contributing factors of life cycle impacts of RAS farming. 


\section{References}

Aubin, J., E. Papatryphon, H. M. G. Van der Werf, J. Petit, and Y. M. Morvan. 2006. Characterisation of the environmental impact of a turbot (Scophthalmus maximus) re-circulating production system using Life Cycle Assessment. Aquaculture 261(4): 1259-1268.

Ayer, N. W. and P. H. Tyedmers. 2009. Assessing alternative aquaculture technologies: life cycle assessment of salmonid culture systems in Canada. Journal of Cleaner Production 17(3): 362-373.

Chadwick, E. M. P., G. J. Parsons, and B. Sayavong, eds. 2010. Evaluation of Closed-containment Technologies for Saltwater Salmon Aquaculture. Ottawa, Canada: NRC Research Press.

Davidson, M. R., D. Zhang, W. Xiong, X. Zhang, and V. J. Karplus. 2016. Modelling the potential for wind energy integration on China's coal-heavy electricity grid. Nature Energy 1: 16086.

Ellingsen, H. and S. A. Aanondsen. 2006. Environmental Impacts of Wild Caught Cod and Farmed Salmon A Comparison with Chicken. The International Journal of Life Cycle Assessment 11(1): 60-65.

Ellingsen, H., J. O. Olaussen, and I. B. Utne. 2009. Environmental analysis of the Norwegian fishery and aquaculture industry - A preliminary study focusing on farmed salmon. Marine Policy 33(3): 479-488.

Hognes, E. S., F. Ziegler, and V. Sund. 2011. Carbon footprint and area use of farmed Norwegian salmon. SINTEF project report no. F21039. Trondheim: SINTEF Fisheries and aquaculture.

Katevas, D. S. 2014. Krill meal and krill oil: How price and tonnage competitive are they with other fishmeals and oils? Aquafeed: Advances in Processing \& Formulation 6(4): 12-20.

Liu, B., Y. Liu, and X. Wang. 2015. The effect of stocking density on growth and seven physiological parameters with assessment of their potential as stress response indicators for the Atlantic salmon (Salmo salar). Marine and Freshwater Behaviour and Physiology 48(3): 177-192.

Liu, Y., T. W. Rosten, K. Henriksen, E. S. Hognes, S. Summerfelt, and B. Vinci. 2016. Comparative economic performance and carbon footprint of two farming models for producing Atlantic salmon (Salmo salar): Land-based closed containment system in freshwater and open net pen in seawater. Aquacultural Engineering 71: 1-12.

McGrath, K. P., N. L. Pelletier, and P. H. Tyedmers. 2015. Life Cycle Assessment of a Novel Closed-Containment Salmon Aquaculture Technology. Environmental Science \& Technology 49(9): 5628-5636.

Parker, R. W. R. and P. H. Tyedmers. 2012. Life Cycle Environmental Impacts of Three Products Derived from Wild-Caught Antarctic Krill (Euphausia superba). Environmental Science \& Technology 46(9): 4958-4965.

Pelletier, N., P. Tyedmers, U. Sonesson, A. Scholz, F. Ziegler, A. Flysjo, S. Kruse, B. Cancino, and H. Silverman. 2009. Not All Salmon Are Created Equal: Life Cycle Assessment (LCA) of Global Salmon Farming Systems. Environmental Science \& Technology 43(23): 8730-8736.

Sun, G. X. 2014. Feeding strategy study for Atlantic salmon (Salmo Salar L.) in recirculating aquaculture system (in Chinese). PhD thesis. Qingdao: Institute of Oceanology, Chinese Academy of Sciences.

Ziegler, F., U. Winther, E. S. Hognes, A. Emanuelsson, V. Sund, and H. Ellingsen. 2012. The Carbon Footprint of Norwegian Seafood Products on the Global Seafood Market. Journal of Industrial Ecology 17(1): 103-116. 